\title{
Modeling in Earth system science up to and beyond IPCC AR5
}

\author{
Tomohiro Hajima ${ }^{1}$, Michio Kawamiya ${ }^{1 *}$, Michio Watanabe ${ }^{1}$, Etsushi Kato ${ }^{2,3}$, Kaoru Tachiiri $^{1}$, Masahiro Sugiyama ${ }^{4}$, \\ Shingo Watanabe ${ }^{1}$, Hideki Okajima ${ }^{1}$ and Akinori Ito ${ }^{1}$
}

\begin{abstract}
Changes in the natural environment that are the result of human activities are becoming evident. Since these changes are interrelated and can not be investigated without interdisciplinary collaboration between scientific fields, Earth system science (ESS) is required to provide a framework for recognizing anew the Earth system as one composed of its interacting subsystems. The concept of ESS has been partially realized by Earth system models (ESMs). In this paper, we focus on modeling in ESS, review related findings mainly from the latest assessment report of the Intergovernmental Panel on Climate Change, and introduce tasks under discussion for the next phases of the following areas of science: the global nitrogen cycle, ocean acidification, land-use and land-cover change, ESMs of intermediate complexity, climate geoengineering, ocean $\mathrm{CO}_{2}$ uptake, and deposition of bioavailable iron in marine ecosystems. Since responding to global change is a pressing mission in Earth science, modeling will continue to contribute to the cooperative growth of diversifying disciplines and expanding ESS, because modeling connects traditional disciplines through explicit interaction between them.
\end{abstract}

Keywords: Earth system science; Earth system model; Carbon and nitrogen cycle; Land and ocean $\mathrm{CO}_{2}$ uptake; Ocean acidification; Land-use and land-cover change; EMICs; Geoengineering; Iron deposition

\section{Review}

\section{Introduction}

Changes in the natural environment that are a result of human activities are becoming evident. Although one of the clearest examples is global warming, the problem goes well beyond a single issue and includes ocean acidification and perturbations of the global nitrogen cycle from industrial fixation. These issues are interrelated, and no single one can be addressed without interdisciplinary collaboration between scientific fields such as meteorology, oceanography, geochemistry, biology, and even social sciences. Recognizing the situation, scientists have been debating the necessity of 'Earth system science' (ESS), in which the global environment is recognized as a system composed of its interacting subsystems - the atmosphere, oceans, biosphere, cryosphere, and society.

\footnotetext{
* Correspondence: kawamiya@jamstec.go.jp

${ }^{1}$ Yokohama Institute for Earth Sciences, Japan Agency for Marine-Earth Science and Technology, 3173-25 Showa-machi, Kanazawa-ku, Yokohama 236-0001, Japan

Full list of author information is available at the end of the article
}

Based on preceding studies on the concept of ESS, a report by the NASA Advisory Council (1988) first used the term 'Earth system science' explicitly and provided the clear definition used today. The report set the goal of ESS as the scientific understanding of the entire Earth system on a global scale by describing how its component parts and their interactions have evolved, how they function, and how they may be expected to continue to evolve on all time scales. The report points out that accomplishing this goal will require various research schemes such as numerical modeling, global observation systems, and information networks that enable efficient dissemination of observed data and research outputs. The statements made showed surprising foresight considering that at the time of publication, the use of the Internet was limited to certain advanced institutes and there were very few attempts to incorporate biogeochemical processes into general circulation models (GCMs).

\section{Models used in Earth system science}

As the aforementioned report emphasized, modeling can be a powerful tool for investigating the dynamics of the

\section{实}


Earth system. Models that have been developed and applied for this purpose can be categorized by their degree of complexity and integration. Models in the 'conceptual' category, which are the least complex, consist of several simple equations mimicking certain aspects of complex behaviors of the Earth system (e.g., Budyko 1969; Sellers 1969). The degree of abstraction is, however, extremely high for this type of model, and correspondence between model equations and processes in nature is not readily understood. This leads to a fundamental difficulty in estimating model parameter values. Models in this category are therefore mainly used for educational purposes or as supporting material for constructing a theoretical framework and are rarely used for projection.

In contrast, atmospheric and oceanic GCMs have been applied to the projection of El Niño events, global warming, and others. GCM-based Earth system models (ESMs), which are introduced in the next section, have a drawback in that they are computationally expensive. To fill the gap between conceptual models and GCMs, ESMs of intermediate complexity (EMICs) are now being extensively developed (Claussen et al. 2002). EMICs greatly simplify equations of motion for the atmosphere and ocean and radiation processes, retaining some ability to reproduce realistic properties such as geographic temperature distribution and deep water formation. EMICs require much less in terms of computer resources and can be integrated for many thousands of years without supercomputers.

With careful experiment design, EMICs constitute an important element for future projection and interpretation of past events with time scales longer than approximately a few hundred years (e.g., Timmermann et al. 2009; Hargreaves et al. 2012). However, the same drawback of substantial abstraction for conceptual models applies to EMICs, albeit to a lesser extent. It is desirable to make parallel and complementary use of GCM-based ESMs and EMICs within computer resource availability.

Many institutes in the world involved in global warming projection are developing elaborate ESMs by coupling biogeochemical modules (vegetation dynamics, the carbon cycle, and others) with GCMs (Figure 1). This figure shows components specific to the Model for Interdisciplinary Research on Climate, Earth System Model (MIROC-ESM; Watanabe et al. 2011). This is a GCM-based ESM developed by the Japan Agency for Marine-Earth Science and Technology (JAMSTEC), with collaboration from The University of Tokyo Atmosphere Ocean Research Institute (AORI) and National Institute for Environmental Studies (NIES). Most ESMs developed by leading institutes have similar structures. One of the most striking findings from studies using ESMs is that there is positive feedback between climate change and the carbon cycle (IPCC 2013), mainly caused by response of the terrestrial biosphere to rising temperature.

For coupling the carbon cycle to climate models, a new method of climate-carbon cycle simulation has been devised and adopted as a common method of climate-carbon cycle projection. Traditionally, ESMs are driven by ' $\mathrm{CO}_{2}$ emission', in which future climate change is projected by internally predicted $\mathrm{CO}_{2}$ concentration based on prescribed anthropogenic $\mathrm{CO}_{2}$ emission (e.g., Friedlingstein et al. 2006; Yoshikawa et al. 2008; Friedlingstein et al. 2014). This type of simulation reflects the actual sequence of the global carbon cycle and is therefore very intuitive. However, it is difficult to

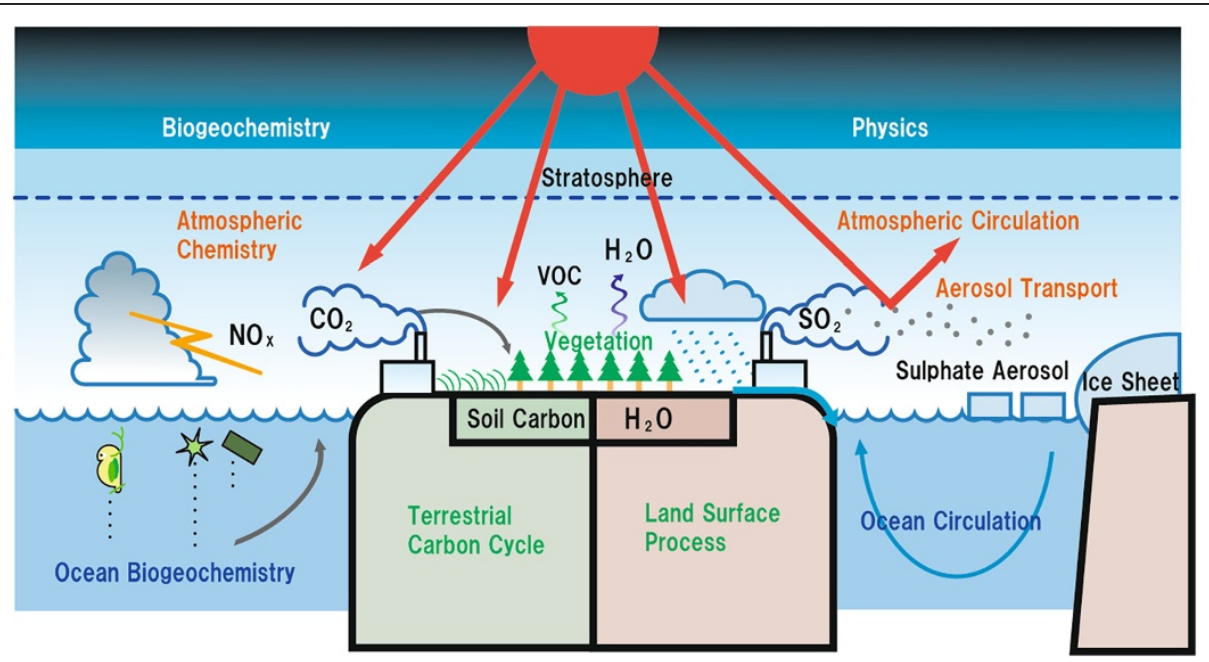

Figure 1 Components in MIROC-ESM. The MIROC-ESM is a GCM-based earth system model developed jointly by the Japan Agency for Marine-Earth Science and Technology, Center for Climate System Research of the University of Tokyo, and the National Institute for Environmental Studies. 
effectively compare ESM results with other conventional GCMs, because different $\mathrm{CO}_{2}$ concentrations are referenced in these two types of climate model.

Alternatively, in the new method, with so-called 'concentration-driven' simulations, the rates of the atmosphereocean and atmosphere-land $\mathrm{CO}_{2}$ exchanges are diagnosed in ESMs by referring to the prescribed $\mathrm{CO}_{2}$ concentration and predicted climate. Because uncertainty arising from carbon cycle processes can be excluded in the projected climate, we can effectively compare climaterelated variables (such as temperature and climate sensitivities) between ESMs and GCMs (e.g., Andrews et al. 2012; Knutti et al. 2013). Another feature of this concentration-driven method is that by using the prescribed $\mathrm{CO}_{2}$ concentration and diagnosed $\mathrm{CO}_{2}$ fluxes, we can inversely estimate the anthropogenic $\mathrm{CO}_{2}$ emission that is allowed to achieve the prescribed $\mathrm{CO}_{2}$ concentration pathways. Since the rate of emission is almost equivalent to that of anthropogenic fossil fuel $\mathrm{CO}_{2}$, this inversely estimated $\mathrm{CO}_{2}$ emission in the experiments is sometimes called 'allowable' or 'compatible' emission. For example, in the study of Jones et al. (2013), compatible emissions simulated by ESMs were compared by applying prescribed $\mathrm{CO}_{2}$ pathways of representative concentration pathways (RCPs). These authors found that about half the participating models predicted that 'negative' anthropogenic emissions will be necessary during the twenty-first century to realize RCP2.6 scenarios. As such information from the concentration-driven experiments has a direct implication for future climate mitigation policies, this simulation style is now becoming popular among those who use ESMs, suggesting a new application of models in ESS for global environmental change projections.

\section{Future directions}

It has been pointed out that the behavior of the simulated terrestrial biosphere may be drastically changed if one includes the nitrogen cycle. The intensity of climate-carbon cycle feedback based on models with a global nitrogen cycle will be an issue of great interest for the possible next phase of the Intergovernmental Panel on Climate Change (IPCC) assessment, as explained in the 'Nitrogen cycle' section.

Although the ocean exhibits feedback caused by the temperature dependence of the $\mathrm{CO}_{2}$ solubility in seawater, its intensity is about a quarter of that of the terrestrial biosphere, at least under the current setup of typical ESMs, often without a terrestrial nitrogen cycle (IPCC 2013). The projection of the ocean uptake of $\mathrm{CO}_{2}$ is nevertheless critical, because the ocean will be the primary sink of anthropogenic $\mathrm{CO}_{2}$ (details in 'Ocean $\mathrm{CO}_{2}$ uptake' section) and the uptake causes another problem, ocean acidification caused by the weak acidity of $\mathrm{CO}_{2}$.
The ocean acidification problem is reviewed in more detail in the 'Ocean acidification' section.

It is sometimes purported that the role of global environmental projection is gradually changing from science used as a warning to that which can be implemented (Kerr 2011). Indeed, 'actionable science' was the watchword in the 2011 Open Science Conference of the World Climate Research Programme (WCRP) in Denver (Asrar et al. 2012). Climate models can serve society in many ways, such as providing information on extreme weather. ESMs are particularly useful for reflecting scientific perceptions of future socioeconomic scenarios. Components of ESMs for global cycles of carbon and other biogeochemical properties can act as a bridge between socioeconomic models, whose outputs are frequently greenhouse gas emissions, and climate models, which require concentrations of the gases. Another aspect of the way in which ESMs are helpful for linking climate science and the socioeconomy is that they can deal with land-use change (LUC) processes, a key factor for the future global carbon budget and regional climate change. Issues of LUC are surveyed in the 'Land-use and land-cover change' section. Care must be taken regarding uncertainties when ESM results are applied to developing socioeconomic scenarios. Uncertainties in parameter values of ESMs are even more serious than those in conventional climate models, because ESMs incorporate biological processes such as photosynthesis. Parameter ensemble experiments are desirable but not always feasible, owing to the computational cost of GCM-based ESMs. Using GCM-based ESMs and EMICs in parallel may remedy this problem, as discussed in the section titled 'Earth system models of intermediate complexity'.

Actionable science might go well beyond just providing information. Artificial, active modification of the global climate, often termed geoengineering, is now a matter of debate. The Fifth Assessment Report (AR5) of IPCC (IPCC 2013) treated this issue in multiple chapters. This should, however, be regarded as a last resort since most of its side effects are yet to be assessed and there will undoubtedly be many others of which we are not yet aware. Scientists have started a project to evaluate the effects of geoengineering using numerical models. Results from that project will be introduced in the section titled 'Climate geoengineering, together with other aspects of geoengineering presented in the 'Ocean $\mathrm{CO}_{2}$ uptake' and 'Atmospheric deposition of bioavailable iron in marine ecosystems' sections.

This review is not intended to cover all subjects that can be tackled with ESMs. Paleoclimate is an example of topics missing here, but this does not mean that the authors consider paleoclimate to be unimportant. Rather, collaboration between communities of paleoclimate and global environmental change projection is critical to 
enhancing the credibility of future projection, since paleoclimate provides the only means for validating climate models on time scales longer than decades. A limited number of topics are addressed in this review, from an extremely large number of fields in which ESMs can be applied.

\section{Nitrogen cycle}

Modern Earth system modeling may be said to have begun by incorporating land/ocean carbon cycle processes into GCMs (Cox et al. 2000). The latest ESMs are now equipped with more complex and interactive processes on global chemical/biogeochemical processes, such as atmospheric chemistry. Recent studies analyzing simulation results from the Coupled Model Intercomparison Project phase 5 (CMIP5) ESMs suggest the importance of the global nitrogen cycle, particularly the process of nitrogen shortage and its limitation on ecosystem productivity (Arora et al. 2013; Hajima et al. 2014). This deficiency of available nitrogen could alter the behavior of the global carbon cycle, thereby impacting the global climate. In addition, from the beginning of the twentieth century, the global nitrogen cycle has been greatly perturbed by the human creation of reactive nitrogen and anthropogenic emission of large amounts of $\mathrm{N}_{2} \mathrm{O}$, one of the strongest greenhouse gases (Gruber and Galloway 2008). To quantify historical human effects on the global nitrogen cycle and make projections for future climate change, ESMs with an explicit nitrogen cycle can be a powerful tool. Here, we first summarize the interaction of climate and the carbon cycle and then describe the impacts of the global nitrogen cycle on the climate by regulating the global carbon budget. Finally, the direct impacts of the nitrogen cycle on the climate due to the production of greenhouse and associated gases are briefly summarized.

\section{Feedback on carbon cycle from environmental changes}

The global carbon cycle has long been regarded as one of the major components that control the global climate because $\mathrm{CO}_{2}$ in the atmosphere has a greenhouse effect and its concentration is regulated by ocean and land ecosystems through the exchange of $\mathrm{CO}_{2}$ with the atmosphere. Furthermore, human activities such as fossil fuel combustion, land-use change, and cement production have released large amounts of $\mathrm{CO}_{2}$ into the air. Its concentration is now reaching 400 ppmv, which corresponds to about a $40 \%$ increase from the preindustrial state. Changes of global carbon balance in the industrial era can be simply understood by

$$
\mathrm{FF}=\Delta C_{\mathrm{A}}+\Delta C_{\mathrm{L}}+\Delta C_{\mathrm{O}}
$$

where FF is the cumulative amount of carbon emitted by fossil fuel combustion and $\Delta C$ represents the changes in the carbon amounts from the preindustrial state of the atmosphere $(\mathrm{A})$, ocean $(\mathrm{O})$, and land $(\mathrm{L})$. In this formulation, the partitioning of emitted carbon between the atmosphere, ocean, and land ecosystems is variable; environmental changes such as global warming can change the capability of carbon uptake by land and the ocean and thereby alter the airborne fraction of emitted $\mathrm{CO}_{2}$ (Le Quéré et al. 2013; Jones et al. 2013 for treatment of land-use change effects on the global carbon balance). For example, global warming could induce large ecosystem respiration and thus reduce total terrestrial carbon. To understand such interactive behavior of the carbon cycle and climate, Friedlingstein et al. (2003) proposed a simple mathematical expression to link carbon balance and environmental changes:

$$
\Delta C_{\mathrm{L}, \mathrm{O}}=\beta_{\mathrm{L}, \mathrm{O}} \Delta C_{\mathrm{A}}+\gamma_{\mathrm{L}, \mathrm{O}} \Delta T
$$

The first term on the right represents a change in the amount of stored carbon due to an atmospheric $\mathrm{CO}_{2}$ increase, assuming a linear response of carbon storage to increasing atmospheric $\mathrm{CO}_{2}\left(\Delta C_{\mathrm{A}}\right)$ with coefficient $\beta$. This environmental effect on carbon storage is sometimes called ' $\mathrm{CO}_{2}$-carbon feedback'. Because an increased $\mathrm{CO}_{2}$ concentration promotes carbon uptake by land and oceans (by stimulating photosynthesis in land ecosystems and increasing the $\mathrm{CO}_{2}$ partial pressure deficit between the atmosphere and oceans), $\beta$ is considered to have a positive sign (i.e., $\mathrm{CO}_{2}$-carbon feedback is negative) (Arora et al. 2013; Friedlingstein et al. 2006; Gregory et al. 2009). The second term represents a carbon storage change in response to climate change (represented by $\Delta T$, the degree of warming); this process is called 'climate-carbon feedback'. Since warming could cause larger ecosystem respiration and a reduction of $\mathrm{CO}_{2}$ dissolution in water, the feedback parameter $\gamma$ is regarded to have a negative sign (Arora et al. 2013; Friedlingstein et al. 2006; Gregory et al. 2009), meaning that interaction between climate and the carbon cycle forms a positive feedback loop.

By combining these two equations, we obtain an expression that incorporates environmental change $\left(\Delta C_{\mathrm{A}}\right.$ and $\left.\Delta T\right)$ into the global carbon balance:

$$
\mathrm{FF}=\Delta C_{\mathrm{A}}+\beta_{\mathrm{L}, \mathrm{O}} \Delta C_{\mathrm{A}}+\gamma_{\mathrm{L}, \mathrm{O}} \Delta T
$$

This equation indicates that cumulative carbon contained in fossil fuel emission increases atmospheric carbon $\left(\Delta C_{\mathrm{A}}\right)$, but carbon partitioning in the atmosphere depends on the land/ocean carbon cycle response, $\mathrm{CO}_{2}$-carbon $\left(\beta \Delta C_{\mathrm{A}}\right)$ and climate-carbon $(\gamma \Delta T)$ feedbacks. A recent study by Arora et al. (2013) in CMIP5 compared these feedback strengths for nine ESMs via sensitivity analysis (Table 1), showing that land and ocean carbon cycles have comparable levels of $\mathrm{CO}_{2}$-carbon feedback. As multimodel means, $\beta$ was $0.92 \mathrm{PgC} \mathrm{ppmv}^{-1}$ for land and 0.80 
Table 1 Equilibrium climate sensitivity (ECS), and concentration $(\beta)$ and climate $(\gamma)$ carbon cycle feedback strengths

\begin{tabular}{lcc}
\hline EMICs (8 models) & $\begin{array}{c}\text { CMIP5 ESMs (15 models for } \\
\text { ECS, 9 models for others) }\end{array}$ \\
\hline$E C S(\mathrm{~K})$ & $3.04 \pm 0.67$ & $3.37 \pm 0.83$ \\
$\beta_{\mathrm{L}}(\mathrm{PgC} / \mathrm{ppm})$ & $0.69 \pm 0.31$ & $0.92 \pm 0.44$ \\
$\beta_{\circ}(\mathrm{PgC} / \mathrm{ppm})$ & $0.93 \pm 0.19$ & $0.80 \pm 0.07$ \\
$\gamma_{\mathrm{L}}(\mathrm{PgC} / \mathrm{K})$ & $-61.5 \pm 29.7$ & $-58.4 \pm 28.5$ \\
$\gamma_{\circ}(\mathrm{PgC} / \mathrm{K})$ & $-9.6 \pm 6.7$ & $-7.8 \pm 2.9$ \\
\hline
\end{tabular}

These parameters were estimated by EMICs and ESMs. Variables were obtained from Eby et al. (2013) for EMICs and from Andrews et al. (2012) and Arora et al. (2013) for ESMs. L, land; O, ocean.

for the ocean. The climate-carbon feedback for land was greater (negative) than that for the ocean, at -58.4 and $-7.8 \mathrm{PgC} \mathrm{K}^{-1}$ respectively. In their simulations, although the $\mathrm{CO}_{2}$ growth rate was rapid $\left(\mathrm{CO}_{2}\right.$ increase of $1.0 \%$ year $^{-1}$ during 140 simulation years) and thus substantial global warming was expected, most ESMs showed that $\mathrm{CO}_{2}$-carbon feedback surpassed climate-carbon feedback across all simulation periods, so natural carbon sinks continued to absorb anthropogenic carbon in the simulations.

\section{Nitrogen cycle feedback on carbon cycle}

The global nitrogen cycle is one of the most important biogeochemical cycles, together with that for carbon. Although the total mass flux of global nitrogen is much smaller than that of carbon (Gruber and Galloway 2008), the nitrogen cycle may have strong impacts on the carbon cycle. Since nitrogen is used by organisms to make amino acids, enzymes, proteins, and nucleic acids, the nitrogen cycle in ecosystems is intimately associated with the life functions of organisms. It is used to develop organisms' bodies, maintain their activity, and increase their populations (Canfield et al. 2010). However, since most nitrogen in nature is in an inactive form $\left(\mathrm{N}_{2}\right)$, nitrogen in reactive and available forms for ecosystems (such as ammonia and nitrous oxide) may be rare and thus often be a limiting factor for ecosystem productivity. This deficiency of nitrogen can strongly restrict carbon fluxes in ecosystems, hence having a feedback effect on the global climate.

In Equation 3, the nitrogen cycle feedback on the climate-carbon cycle system can be summarized as follows. First, the amount of available nitrogen for plants and phytoplankton can control their productivity and the resultant carbon fluxes out of the atmosphere to land or ocean. As shown by free-air $\mathrm{CO}_{2}$ enrichment studies, an elevated $\mathrm{CO}_{2}$ concentration on land can stimulate photosynthesis and accumulate biomass. However, if the amount of available nitrogen does not meet demands for plant growth, the plant biomass accumulation rate is likely constrained (e.g., Reich et al. 2006; Reich and Hobbie 2013). For ocean ecosystems, the gross productivity of phytoplankton and its spatial distribution are originally and strongly regulated by the available nitrogen amount, even in current conditions (Canfield et al. 2010). Because most terrestrial ecosystem models in ESMs are now incapable of explicitly representing the influence of a nitrogen deficit on photosynthetic capacity or other physiological aspects (e.g., leaf area), nitrogen feedback should be reflected by the parameter $\beta$ to weaken the strength of negative $\mathrm{CO}_{2}$-carbon feedback. In fact, some CMIP5 ESMs incorporating explicit terrestrial nitrogen cycle processes show a weaker response to increasing $\mathrm{CO}_{2}$ than those output by other models, which is likely due to the nitrogen-limited response of plant productivity in an enriched $\mathrm{CO}_{2}$ world (Arora et al. 2013; Hajima et al. 2014).

Furthermore, the nitrogen cycle on land could affect the carbon storage response to climate change, as represented by parameter $\gamma$ in Equation 3. Since global warming could lead to enhanced activities of soil microbes, accelerated soil decomposition may reduce the total amount of soil carbon. However, accompanied by the release of inorganic nitrogen that becomes soil nutrients, this accelerated soil decomposition rate might activate plant productivity. In fact, some models incorporating explicit terrestrial nitrogen cycle processes reduce the carbon cycle response to global warming, with less negative or sometimes slightly positive values for $\gamma$ (Sokolov et al. 2008; Bonan and Levis 2010; Thornton et al. 2009; Zaehle et al. 2010). In these models, although global warming reduces soil carbon storage because of enhanced heterotrophic respiration, increasing soil nutrients somewhat compensates the global terrestrial carbon reduction by increasing vegetation carbon storage.

The global nitrogen cycle could alter the global climate by changing both the $\mathrm{CO}_{2}$-carbon and climate-carbon feedback, thereby creating climate-carbon-nitrogen interactions. Although the number of studies is limited, ESMs with a nitrogen cycle show a similar trend in that the incorporation of a nitrogen cycle reduces the sensitivity of the carbon cycle response to environmental changes. However, constraints of the nitrogen cycle on the carbon cycle should be addressed with the presence of reactive nitrogen in the atmosphere, as described below.

\section{Direct impact of the nitrogen cycle on climate and human perturbations}

In the previous section, we described nitrogen cycle feedbacks on the climate through the regulation of carbon cycle responses. In addition, the nitrogen cycle directly impacts global climate because the greenhouse gas $\mathrm{N}_{2} \mathrm{O}$ has a relatively long lifetime in the atmosphere, 
more than 100 years. Galloway et al. (2004) estimated the total $\mathrm{N}_{2} \mathrm{O}$ emission under conditions before the significant human perturbation at approximately $12 \mathrm{TgN}$ year $^{-1}$. Its emission rate has greatly increased during the industrial era because human activities such as industrial nitrogen fixation for fertilizer, fossil fuel/biomass combustion, and agriculture have increased the total amount of reactive nitrogen globally (Galloway et al. 2004; Gruber and Galloway 2008). Some studies using data assimilation or inversion techniques established the current total global $\mathrm{N}_{2} \mathrm{O}$ emission at approximately $18 \mathrm{TgN}_{\text {year }}{ }^{-1}$, and the contribution of the anthropogenic emission to the global total at approximately one third (Saikawa et al. 2013 estimate for 2002 to 2005). The latter emission has increased its concentration in the atmosphere and thus $\mathrm{N}_{2} \mathrm{O}$ radiative forcing is now considered to be $0.17 \mathrm{~W} \mathrm{~m}^{-2}$, about $10 \%$ of $\mathrm{CO}_{2}$ radiative forcing (IPCC 2013). Furthermore, such human activities have created other forms of reactive nitrogen, namely, $\mathrm{NO}_{x}, \mathrm{NH}_{x}$, and $\mathrm{NO}_{y}$. Nitrogen in these reactive forms interacts with global and local climates by contributing to the formation of aerosols, acting as a precursor for generating tropospheric ozone, and through its association with $\mathrm{CH}_{4}$ reduction (Menon et al. 2007).

Reactive nitrogen in these forms may further affect carbon-nitrogen interactions. Since net radiative forcing of these agents is positive (IPCC 2013), there could be an additional warming that could accelerate soil decomposition and modify carbon cycle feedbacks on the climate. In addition, since inorganic mineral nitrogen could be an ecosystem resource for productivity, its deposition on land and ocean surfaces could also have indirect impacts on the climate by alleviating the nitrogen limitation on productivity (e.g., Bonan and Levis 2010; Thornton et al. 2009). Although it is important to assess the combined effect of direct (changing atmospheric composition of non- $\mathrm{CO}_{2}$ greenhouse gases) and indirect (changing $\mathrm{CO}_{2}$ concentration via modulating carbon cycle feedbacks) impacts of the nitrogen cycle on the global climate, the number of related studies is limited (e.g., Stocker et al. 2013; Zaehle et al. 2011). For comprehensive understanding of the influence of human activity on the global nitrogen cycle and its propagation impacts on the global environment, it is hoped that more scientific efforts will be made using fully coupled carbonnitrogen-climate models.

\section{Ocean acidification}

\section{Definition of ocean acidification}

The emission of large amounts of anthropogenic carbon dioxide has increased the global atmospheric $\mathrm{CO}_{2}$ concentration and contributes to temperature increases in the atmosphere and ocean. Since 1750, the global ocean has absorbed about a third of anthropogenic $\mathrm{CO}_{2}$ released into the atmosphere (Sabine et al. 2004; Sabine and Feely 2007). $\mathrm{CO}_{2}$ reacts with water molecules $\left(\mathrm{H}_{2} \mathrm{O}\right)$ to form the weak acid $\mathrm{H}_{2} \mathrm{CO}_{3}$ (carbonic acid), and most of this acid dissociates into hydrogen ions $\left(\mathrm{H}^{+}\right)$and bicarbonate ions $\left(\mathrm{HCO}_{3}^{-}\right)$, such as

$$
\begin{aligned}
& \mathrm{H}_{2} \mathrm{O}+\mathrm{CO}_{2} \leftrightarrow \mathrm{H}_{2} \mathrm{CO}_{3} \\
& \mathrm{H}_{2} \mathrm{CO}_{3} \leftrightarrow \mathrm{H}^{+}+\mathrm{HCO}_{3}^{-}
\end{aligned}
$$

Some of the resulting $\mathrm{H}^{+}$reacts with carbonate ions $\mathrm{CO}_{3}{ }^{2-}$ to produce additional $\mathrm{HCO}_{3}^{-}$ions.

$$
\mathrm{H}^{+}+\mathrm{CO}_{3}^{2-} \leftrightarrow \mathrm{HCO}_{3}^{-}
$$

As a result, $\mathrm{CO}_{2}$ dissolution in the ocean increases $\mathrm{H}^{+}$ (thereby decreasing $\mathrm{pH}$ ) and reduces $\mathrm{CO}_{3}^{2-}$ concentrations, a process known as ocean acidification (Broecker and Clark 2001; Caldeira and Wickett 2003, 2005; Doney et al. 2009). Figure 2 shows a time series of the atmospheric $\mathrm{CO}_{2}$ at Mauna Loa as well as the surface ocean $\mathrm{CO}_{2}$ partial pressure $\left(\mathrm{pCO}_{2}\right)$ and surface ocean $\mathrm{pH}$ at the ocean station ALOHA in the subtropical North Pacific Ocean. We see that as atmospheric $\mathrm{CO}_{2}$ rises, some extra $\mathrm{CO}_{2}$ is transferred into ocean surface waters, leading to ocean acidification. The $\mathrm{pH}$ of ocean surface waters has decreased by about 0.1 since the dawn of the industrial era (Caldeira and Wickett 2003, 2005), with a decrease of approximately 0.0018 year $^{-1}$ observed over the last quarter century at several open-ocean time-series sites (Bates 2007; Bates and Peters 2007; Santana-Casiano et al. 2007; Dore et al. 2009).

Marine calcifying organisms such as plankton, shellfish, coral, and fish use carbonate ions $\mathrm{CO}_{3}{ }^{2-}$ to build their shells or skeletons from calcium carbonate $\left(\mathrm{CaCO}_{3}\right)$,

$$
\mathrm{Ca}^{2+}+\mathrm{CO}_{3}^{2-} \leftrightarrow \mathrm{CaCO}_{3}
$$

so they are expected to be greatly affected by ocean acidification. The carbonate ion concentration is often expressed by the degree of saturation of biominerals aragonite $\left(\Omega_{\mathrm{Ar}}\right)$ and calcite $\left(\Omega_{\mathrm{Ca}}\right)$ (Feely et al. 2004). Shell and skeleton formation generally occurs in supersaturated sea water $\Omega>1$ and dissolution in undersaturated seawater $\Omega<1$. Consequently, spatial and temporal changes in saturation state with respect to these mineral phases are important for understanding how ocean acidification might substantially impact future ecosystems.

\section{Assessment by ESMs}

We can assess the ocean's present and future ability to take up anthropogenic $\mathrm{CO}_{2}$ and the influence of ocean acidification using ESMs in which the ocean carbon cycle is included. Multi-model projections using ocean processbased carbon cycle models have demonstrated large decreases in $\mathrm{pH}$ and carbonate ion concentration $\mathrm{CO}_{3}^{2-}$ 


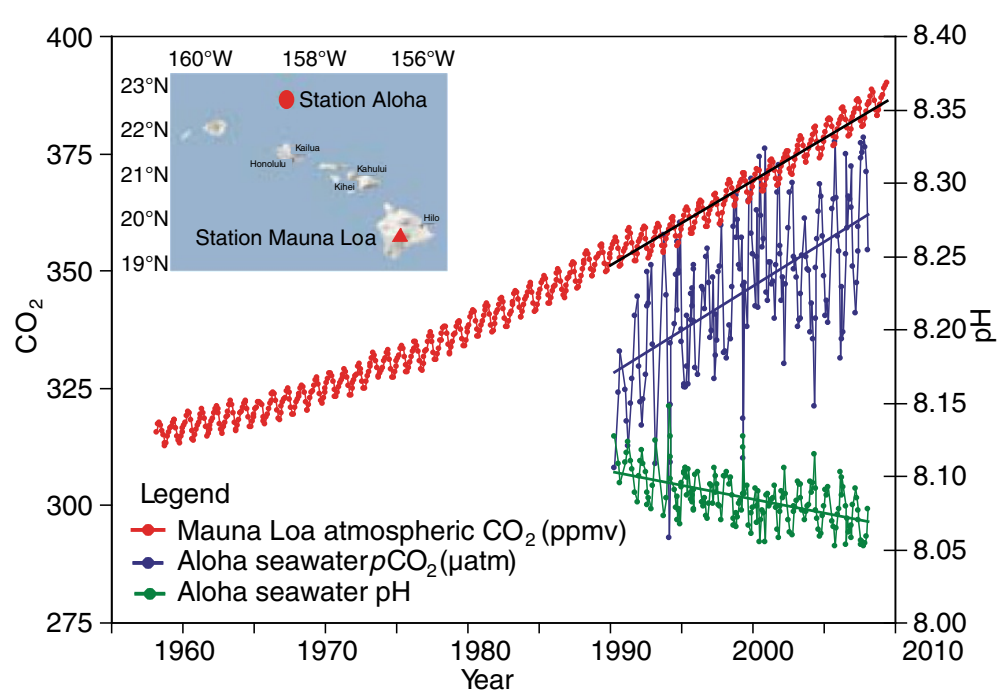

Figure 2 Observed partial $\mathrm{CO}_{2}$ pressure $\left(\mathrm{pCO}_{2}\right)$ and ocean $\mathrm{pH}$ at ocean surface. $\mathrm{pCO}_{2}$ ( $\mu$ atm; blue) and surface ocean $\mathrm{pH}$ (green) at ocean are observed at Station ALOHA in subtropical North Pacific Ocean, in comparison with atmospheric $\mathrm{CO}_{2}$ concentration observed at Mauna Loa (in parts per million by volume; red). Note that the increase in oceanic $\mathrm{CO}_{2}$ over the past 17 years is consistent with the atmospheric increase, within the statistical limits of the measurements (Doney et al. 2009).

during the twenty-first century, across all the world's oceans. By the middle of the present century, atmospheric $\mathrm{CO}_{2}$ levels could reach more than $500 \mathrm{ppm}$ and exceed $800 \mathrm{ppm}$ by the end of the century (Friedlingstein et al. 2006, 2014). By 2100, these $\mathrm{CO}_{2}$ levels would result in an additional decrease of surface water $\mathrm{pH}$ by 0.3 units over current conditions and 0.4 over the preindustrial level. This represents an increase in the ocean's hydrogen ion concentration $\mathrm{H}^{+}$by 2.5 times relative to the beginning of the industrial era (Orr et al. 2005; Feely et al. 2009). Figure 3 shows the multi-model mean aragonite saturation state averaged over 2006 to 2010 and 2096 to 2100, under a scenario called a RCP (http://www.pik-potsdam. $\mathrm{de} / \sim \mathrm{mmalte} / \mathrm{rcps} /$ ) in AR5. Although the greatest decline of surface $\mathrm{CO}_{3}^{2-}$ occurs in the warmer low and middle latitudes (Feely et al. 2009) where $\Omega_{\mathrm{Ar}}>3$ (Figure 3a,b), it is low $\Omega_{\mathrm{Ar}}$ waters at high latitudes and in upwelling regions that first become undersaturated with respect to aragonite. ESMs show that this aragonite undersaturation in surface waters is reached before the end of the twenty-first century in the Southern Ocean (Orr et al. 2005). Steinacher et al. (2009) suggested that aragonite undersaturation occurs sooner and is more intense in the Arctic. When atmospheric $\mathrm{CO}_{2}$ reaches $428 \mathrm{ppm}, 10 \%$ of Arctic surface waters are projected to become undersaturated. By 2100, atmospheric $\mathrm{CO}_{2}$ will exceed $800 \mathrm{ppm}$ and much of the Arctic surface is projected to become undersaturated with respect to calcite (Feely et al. 2009). This means that surface waters would be corrosive to all $\mathrm{CaCO}_{3}$ minerals.

These changes extend well below the sea surface (Orr et al. 2005). Throughout the Southern Ocean, the entire water column becomes undersaturated with respect to aragonite. During the twenty-first century, the aragonite saturation horizon, representing the limit between undersaturation and supersaturation in the Southern Ocean and subarctic Pacific, shoals to the sea surface. In the North Atlantic, surface waters remain saturated with respect to aragonite, but the aragonite saturation horizon shoals dramatically, e.g., north of $50^{\circ} \mathrm{N}$ it shoals from 2,600 to $115 \mathrm{~m}$. Greater erosion in the North Atlantic is due to deeper penetration of waters with higher concentrations of anthropogenic $\mathrm{CO}_{2}$ from the sea surface (Sarmiento et al. 1992; Gruber 1998; Sabine et al. 2004).

Surface $\mathrm{CaCO}_{3}$ saturation also varies seasonally, particularly at high latitudes, where observed saturation is higher in summer and lower in winter (Merico et al. 2006; Findlay et al. 2008). Future projections using ocean carbon cycle models indicate that undersaturated conditions will be reached first in winter (Orr et al. 2005). In the Southern Ocean, it is projected that wintertime undersaturation with respect to aragonite will begin when atmospheric $\mathrm{CO}_{2}$ reaches $450 \mathrm{ppm}$, which is about $100 \mathrm{ppm}$ sooner (30 years) than for the annual mean undersaturation (McNeil and Matear 2008). Aragonite undersaturation will be reached during wintertime in parts $(10 \%)$ of the Arctic when atmospheric $\mathrm{CO}_{2}$ attains $410 \mathrm{ppm}$ (Steinacher et al. 2009).

\section{Controlling factors}

As mentioned above, future reductions in surface ocean $\mathrm{pH}$ and $\mathrm{CaCO}_{3}$ (calcite and aragonite) saturation states are mostly controlled by the uptake of anthropogenic $\mathrm{CO}_{2}$. Other effects of future climate change counteract less than $10 \%$ of the reductions of $\mathrm{CaCO}_{3}$ saturation 


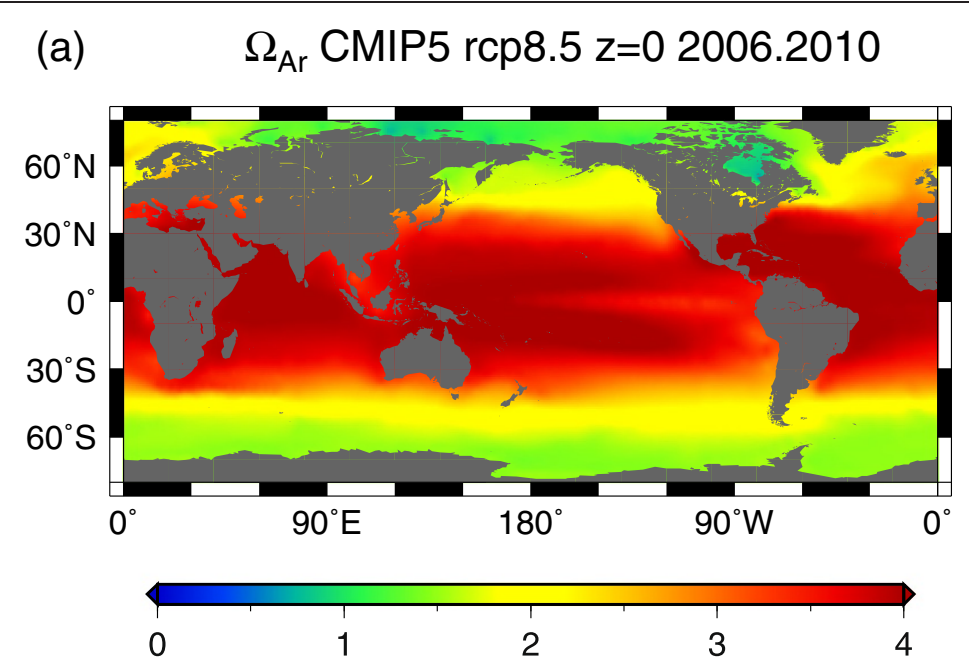

(b) $\Delta \Omega_{\mathrm{Ar}}$ CMIP5 rcp8.5 z=0 2096.2100-2006.2010

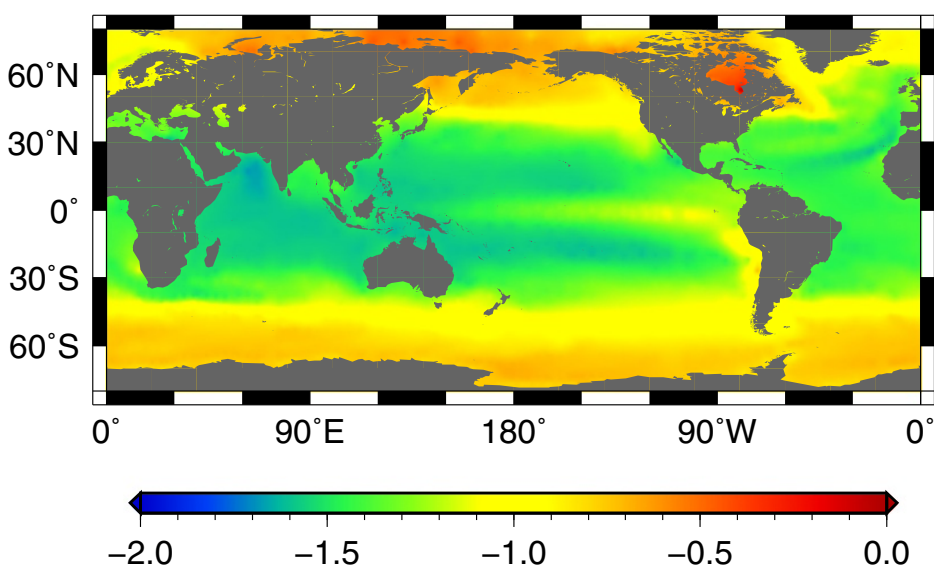

Figure 3 Spatial distribution of aragonite saturation state $\Omega_{\mathrm{Ar}}$. (a) Model-mean $\Omega_{\mathrm{Ar}}$ at the sea surface averaged over 2006 to 2010 , derived from nine CMIP5 ESMs under the AR5 RCP8.5 scenario. (b) Change in $\Omega_{\text {Ar }}$ at the sea surface from 2006-2010 to 2096-2100.

(Orr et al. 2005; McNeil and Matear 2008). An exception is the Arctic Ocean, where decreases in the $\mathrm{pH}$ and aragonite saturation state are predicted to be caused by increased freshwater input from sea ice melt, enhanced precipitation, and stronger air-sea $\mathrm{CO}_{2}$ fluxes because of less sea ice cover (Steinacher et al. 2009; Yamamoto et al. 2012). This result indicates that future projections of the $\mathrm{pH}$ and aragonite saturation state at high latitudes may be significantly influenced by rapid sea ice reduction as well as increases of atmospheric $\mathrm{CO}_{2}$ concentration.

Focusing on the regional ocean carbon cycle, models project some nearshore systems to be highly vulnerable to future $\mathrm{pH}$ decrease. In the California Current system, an eastern upwelling system, strong seasonal upwelling of carbon-rich waters (Feely et al. 2008) makes surface waters sensitive to future ocean acidification, as in the Southern Ocean. In the northwestern European shelf seas, large spatiotemporal $\mathrm{pH}$ variability is enhanced by local effects from river input and organic matter degradation, exacerbating ocean acidification from anthropogenic $\mathrm{CO}_{2}$ invasion (Artioli et al. 2012). In the Gulf of Mexico and East China Sea, coastal eutrophication, another anthropogenic perturbation, has been shown to enhance subsurface acidification as additional respired carbon accumulates at depth (Cai et al. 2011).

\section{Land-use and land-cover change}

On the land surface, about one-third to one-half the area of natural ecosystems has been converted to managed land for use as cropland and pasture over the past 10,000 years (Klein Goldewijk et al. 2011). Human land use is projected to expand in the future because of food and energy demands due to changes in the population and socioeconomic factors (Bruinsma 2009). Anthropogenic 
modification of land cover and its management affect ecosystem functioning and also modifies Earth system atmosphere-biosphere interactions through biogeophysical and biogeochemical effects (Claussen et al. 2001; Pongratz et al. 2010; Sato et al. 2014). Changes in surface albedo and latent and sensitive heat fluxes are principal biogeophysical effects of land-use and landcover changes, which affect atmospheric conditions via changes to the hydrologic cycle and energy balance (Bonan 2008). A striking example of the biogeophysical effect of land-use change is that of historical deforestation at mid and high latitudes, which has increased surface albedo in winter by altering snow cover and lowering surface air temperature (Davin and de NobletDucoudré 2010). In the tropics, deforestation reduces evapotranspiration, which also affects atmospheric conditions (Bala et al. 2007). Furthermore, irrigation and soil management on cropland is known to affect local air temperatures (Lobell et al. 2006).

The dominant biogeochemical effect of historical landuse and land-cover change is an increase in the atmospheric $\mathrm{CO}_{2}$ concentration, through decreases in terrestrial carbon stock via expansion of anthropogenic land use (Sato et al. 2014). About 33\% of total anthropogenic $\mathrm{CO}_{2}$ emissions from the preindustrial era are from land-use change (Houghton et al. 2012). It is also pointed out in several studies (Bouwman et al. 2005; Bodirsky et al. 2012) that increases in atmospheric $\mathrm{N}_{2} \mathrm{O}$, for which the globalwarming potential over 100 years is about 300 times that of $\mathrm{CO}_{2}$, are caused by emissions from the increased use of fertilizer on cropland.

For a quantitative understanding of the biogeophysical and biogeochemical effects of land-use and land-cover change, model intercomparison was first done using EMICs. These couple terrestrial biogeochemical models with simplified lower-resolution climate models (Brovkin et al. 2006) and then GCMs with land surface schemes, with consideration of anthropogenic land-cover type (Pitman et al. 2009). To incorporate changes of landcover type, anthropogenic land use as a fraction of each land-use type for a grid cell in forcing data is assigned annually in the model. To represent biophysical properties of anthropogenic land-use type such as cropland, pasture, and urban (if considered in the land-use data), each plant functional type that has corresponding land surface scheme parameters (such as phenological, morphological, and photosynthetic) is allocated a percentage at a grid cell annually, according to land-use forcing data. Effects on the carbon budget caused by land-cover and land-use change are estimated through carbon emissions from deforestation and wood harvesting. This estimation is done using several product pools with various time scales of decay (McGuire et al. 2001) and additional carbon uptake after the abandonment of cropland by vegetation regrowth, which can be affected by the age distribution of vegetation on secondary land (Shevliakova et al. 2009).

Pongratz et al. (2010) evaluated the effect of land-use change throughout the twentieth century using a GCMbased ESM. They estimated the effect of land-use change on the global mean temperature in the twentieth century to be $-0.03^{\circ} \mathrm{C}$ through biogeophysical effects and $0.18^{\circ} \mathrm{C}$ through biogeochemical effects, giving a net effect of $0.15^{\circ} \mathrm{C}$. Generally, biogeophysical effects of historical landuse change on the global mean surface air temperature are less than biogeochemical effects, because the former operates locally and biogeophysical changes from deforestation (e.g., those of albedo and latent heat flux) sometimes work together to compensate their individual impacts on temperature (Pitman et al. 2009; Pongratz et al. 2010).

\section{Uncertainty of land-use and land-cover change}

In such evaluations of impacts on the atmosphere by global land-use change, large uncertainties persist among model estimates (Sato et al. 2014). For example, in the study of the current global carbon budget, one of the largest uncertainties originates from anthropogenic land-use changes in terrestrial ecosystems. The standard deviation of carbon flux caused by historical anthropogenic landuse change is estimated to be in the order of $\pm 0.5 \mathrm{PgC}$ (Le Quéré et al. 2013). The choice of land-use data could be one of the causes of estimate variations in land-use change emissions (Jain and Yang 2005; Meiyappan and Jain 2012). In the global evaluation of land-use and landuse change effects, land-use data compiled at an approximately $0.5^{\circ} \times 0.5^{\circ}$ spatial resolution are generally used. Uncertainty in gridded historical land-use data derives from differences in cropland and pasture area between datasets, downscaling processes of regionally aggregated data, and others. These uncertainties in the reconstruction of historical land-use data should be considered in model evaluation (Klein Goldewijk and Verburg 2013). In a recent study of the global carbon budget, the standard deviation of estimated land-use change flux with multiple terrestrial carbon cycle models using the same land-use dataset was estimated at $0.42 \mathrm{PgC}_{\text {year }}{ }^{-1}$ (Le Quéré et al. 2013). In contrast, the standard deviation estimated by a single model, which was also used in the multiple model comparison using three different land-use datasets, was 0.27 PgC year ${ }^{-1}$ (Jain et al. 2013).

Care should be taken regarding whether gross transition information between each land-use category in a grid cell is available within the land-use dataset. This is because some models use net changes and others gross changes of land-use type in the calculation of the carbon budget. In addition, there are several other problems in the use of datasets, which may cause further uncertainties because of a lack of detailed protocol for the handling of 
these. These include differences in the implementation of land-use data in the terrestrial ecosystem component among models, and whether the model considers emissions and uptake caused by shifting cultivation, wood harvesting, forest degradation, crop harvesting, peat fires, and others.

\section{LUC in CMIP5 and its future direction}

In CMIP5, anthropogenic land-use and land-use changes were considered in historical and future scenarios simulated by ESMs. Harmonized land-use transition datasets have been prepared through historical (1500 to 2005) and four future RCPs through 2100 (Hurtt et al. 2011). The historical part consists of the reconstructed cropland and pasture dataset 'History Database of the Global Environment' (HYDE) (Klein Goldewijk et al. 2010; Klein Goldewijk et al. 2011) and wood harvest data of the Food and Agriculture Organization (FAO) of the United Nations. Four future scenarios constructed by integrated assessment models (IAMs) were harmonized with the historical data to smoothly connect past and future scenarios in 2005, using consistent land-use categories. These are primary land, secondary land, cropland, pasture, and urban areas, with a $0.5^{\circ} \times 0.5^{\circ}$ horizontal resolution. Annual transitions among these land-use categories, wood harvest area, and carbon mass changes were calculated for each grid cell. In the CMIP5 experiments, ESM modelers used harmonized land-use data as common forcing to consider the effects of land-use change on the terrestrial carbon cycle and biogeophysical effects of land-cover change in climate simulations (Taylor et al. 2012). In addition to the standard CMIP5 experiments, the international project Land-Use and Climate, Identification of Robust Impacts (LUCID) conducted LUCID-CMIP5 experiments using ESMs, in which land use was fixed at 2005 to evaluate future land-use scenarios (Brovkin et al. 2013). Under the LUCID framework, biogeophysical effects and variation of the carbon cycle from future land-use change was evaluated using concentrationdriven simulations of RCP2.6 and RCP8.5 (Brovkin et al. 2013; Boysen et al. 2014). In this simulation, there were no significant impacts on the global climate from biogeophysical changes caused by future land-use change. However, in regions exceeding 10\% land-use change during the scenario period, half the models showed significant impacts of such change on surface temperature. Furthermore, some models revealed significant changes in surface albedo, latent heat flux, and available energy in the $10 \%$ exceedance region. Nevertheless, these biogeophysical effects on climate in the future scenarios were weak because the area of intense land-use change was restricted to tropical and subtropical regions and the changed area was small compared with historical changes. For effects on terrestrial carbon storage, all models showed significant decreases in carbon stock in the two RCP scenarios. Estimations of cumulative carbon emission caused by landuse change varied greatly among the models, suggesting scientific issues in implementing land-use change processes in the ESMs (e.g., some models considered both crop and pasture areas, whereas others treated only cropland; some models used information on gross land-use transitions, whereas others used net transitions).

After the CMIP5 exercise, needs were recognized for more detailed protocols to handle anthropogenic land use and land-use change in land surface models. Consideration of more precise land-use categories and management processes such as irrigation, wood harvest treatment, biofuel crop type, and afforestation have been addressed for the upcoming 6th phase of Coupled Model Intercomparison Project (CMIP6). This is because the future carbon cycle is strongly dependent on the land-use scenario as well as the terrestrial ecosystem response to both future $\mathrm{CO}_{2}$ and climate change (Jones et al. 2013). Toward CMIP6, experiments involving land-use are also considered in specialized intercomparisons that would use CMIP6 standards and infrastructure. In this process, especially for future scenario simulations, the validation of simulated carbon stock in contemporary land ecosystems would be of great importance, because bias in CMIP5 historical simulations is one cause of strong variability in the simulated future changes of carbon stock within CMIP5 and LUCID-CMIP5 simulations (Brovkin et al. 2013; Anav et al. 2013). In addition, C-N interaction for $\mathrm{CO}_{2}$ fertilization effects should be considered because of their strong impacts on vegetation regrowth following land-use change, which in turn affects contemporary and future terrestrial carbon sink trends (Jain et al. 2013).

\section{Earth system models of intermediate complexity}

State-of-the-art GCMs/ESMs furnish irreplaceable future projection data. These models are designed to maximize the representation of detailed processes while retaining reasonable computational speed so that experiments are completed as scheduled, and are unsuitable for executing very long runs or ensemble experiments sufficiently large to extract statistically useful information. In contrast, simple box models aid conceptual understanding, but a lack of geographic detail prevents practical applications and their implications are more qualitative than quantitative. EMICs are designed to fill the gap between the two model types. EMIC results are sometimes included in intermodel comparisons of ESMs, e.g., the Coupled Climate Carbon Cycle Model Intercomparison Project (C4MIP) (Friedlingstein et al. 2006), which shows results comparable to ESMs.

It is said that the history of modern EMICs began with the statistical-dynamical atmosphere model of Petoukhov 
(1980). More than ten models developed prior to Claussen et al. (2002) defined the term EMICs based on three factors: the number of interacting components of the climate system explicitly represented in the model, the number of processes explicitly simulated, and the detail of description. The number of models increased to 13 by the time EMICs were summarized by Claussen (2005). As described below, we had 15 models in the latest EMIC model intercomparison project, and this number is expected to increase further.

In this chapter, we begin with a description of EMICs and a classification and then review past model intercomparison projects to determine inter-model differences between EMICs. Finally, we summarize studies using EMICs and future possibilities, with a special focus on carbon-cycle and anthropogenic emission.

\section{Characteristics and classification of EMICs}

EMICs simplify the atmosphere and/or ocean by reducing the number of represented processes and their dimensions. Also, because EMICs generally use coarser spatial resolution in comparison to GCMs/ESMs, they run at much faster speeds than those models. For example, as in Table 2, on a scalar-type supercomputer, the EMIC Japan Uncertainty Modelling Project Loosely Coupled Model (JUMP-LCM) (Tachiiri et al. 2010; MIROC-lite component, Oka et al. 2011) ran significantly faster than the Atmosphere-Ocean GCM 'MIROC4h', the high-resolution version of MIROC4. It is difficult to say how many times faster because it depends on the degree of parallelization and other factors. However, with the settings in Table 2, JUMP-LCM ran 63,000 times faster than MIROC4h, and also runs significantly faster than a GCM of a medium-resolution version of MIROC4 with the conditions shown in Table 2.

Based on the method of simplification, atmospheric components of EMICs may be classified into four types: 1) statistical-dynamical models, e.g., Climate-Biosphere $3 \alpha$ (CLIMBER-3 $\alpha$ ) (Montoya et al. 2005); 2) energy moisture balance models (EMBM), e.g., University of Victoria (UVic) (Weaver et al. 2001); 3) quasi-geostrophic models, e.g., Loch-Vecode-Ecbilt-Clio-agism Model (LOVECLIM) (Driesschaert 2005); and 4) a new fourth type using primitive equations, e.g., Fast Met Office/UK Universities Simulator (FAMOUS) (Smith 2012). Statistical-dynamical models are based on time-averaged equations, wherein the effects of large-scale atmospheric and oceanic transient eddies are parameterized in terms of climatic means or neglected (Saltzman 1978). The EMBMs are based on the vertically integrated energy-moisture balance equations, and the quasi-geostrophic models are based on a quasi-geostrophic approximation. For the ocean, some use frictional geostrophic models, but many adopt primitive equation models as ocean GCMs.

In the latest EMIC intercomparison project, EMIC AR5, designed for contributing to the IPCC Fifth Assessment Report (AR5) report, there were 15 participant EMICs (http://climate.uvic.ca/EMICAR5/). Of these, four are statistical-dynamic, seven are EMBMs, two are quasigeostrophic, and two are based on primitive equations. Seven models have a 3D atmosphere, up from three (of eight) in the Fourth Assessment Report (AR4) of IPCC (IPCC 2007). For the ocean, eight use primitive equations, four use frictional-geostrophic models, and the rest are mixed-layer or box models. The model with the finest spatial resolution, UVic 2.9 (Weaver et al. 2001), has $1.8^{\circ} \times 3.6^{\circ}$ grids for both the atmosphere and ocean, comparable to GCMs (the atmosphere of UVic 2.9 is, however, 2D). All but one have some type of sea ice scheme. Thirteen have carbon cycle components, 12 marine, and 10 terrestrial. Of the latter, six are dynamic vegetation models. Four models have sediment and weathering components (Eby et al. 2013). Table 3 is a classification of these models, based on the ecosystem components.

Zonal mean surface air temperature in the present climate is well represented by EMICs, at least to a degree similar to GCMs (IPCC 2007). However, it is generally difficult for EMICs to represent the spatial distribution

Table 2 Model specifications and benchmarks: EMIC versus GCMs (supercomputer at JAMSTEC)

\begin{tabular}{|c|c|c|c|}
\hline Model & $\begin{array}{c}\text { JUMP-LCM } \\
\text { (Tachiiri et al. 2010) }\end{array}$ & $\begin{array}{c}\text { MIROC4h } \\
\text { (Sakamoto et al. 2012) }\end{array}$ & $\begin{array}{c}\text { MIROC4 } \\
\text { (unreleased version) }\end{array}$ \\
\hline Horizontal grids (atmosphere) & $60 \times 30$ & $640 \times 320$ & $128 \times 64$ \\
\hline Vertical layers (atmosphere) & 1 & 56 & 20 \\
\hline Horizontal grids (ocean) & $60 \times 30$ & $1,280 \times 912$ & $256 \times 224$ \\
\hline Vertical layers (ocean) & 15 & 48 & 41 \\
\hline Time step & $36 \mathrm{~h}$ & Atmosphere: variable; ocean: 3 min & Atmosphere and ocean: 20 min \\
\hline Components & $\begin{array}{l}\text { Atmosphere and ocean: with carbon } \\
\text { cycle, land: carbon cycle }\end{array}$ & Physics in atmosphere, ocean, land & \\
\hline Computer & Scalar & Scalar & Vector \\
\hline CPU used & 1 & 20 & 4 \\
\hline Speed (s/year) & 15 & 944,620 & 12,958 \\
\hline
\end{tabular}


Table 3 Classification of EMICs based on ecosystem components

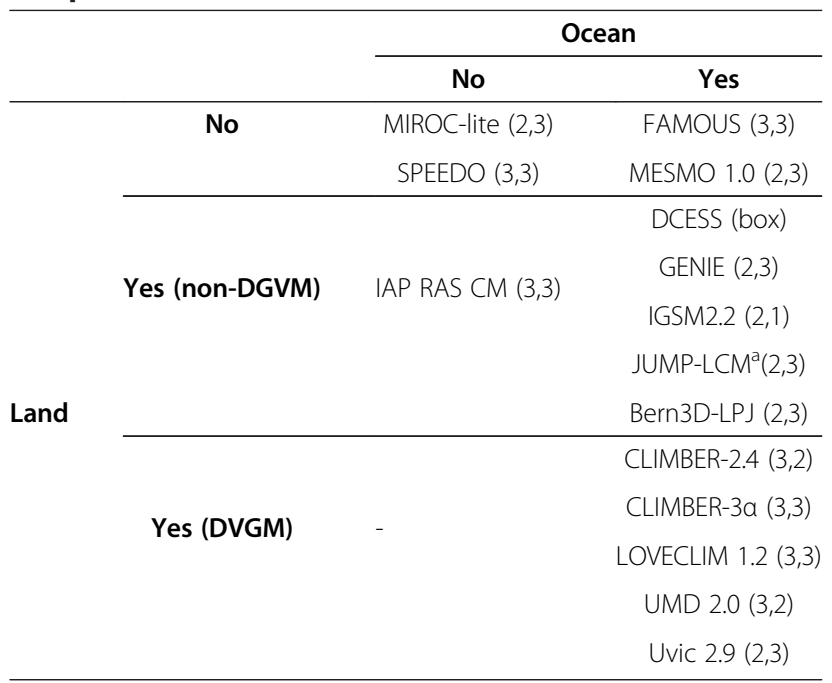

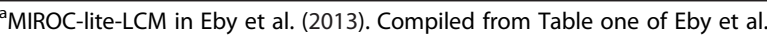
(2013), based on the presence of ocean/land ecosystem components. Numbers in parentheses after model names indicate dimensions of atmosphere and of ocean. For references on each model, see Eby et al. (2013).

of precipitation, and so it is not easy to couple them to vegetation models. This is particularly so for EMBMs. Figure 4 shows JUMP-LCM output and a comparison with observation for atmospheric temperature and precipitation. The spatial distribution of temperature is relatively well represented, even by the EMIC with a 2D atmosphere (Figure 4c). However, Figure 4d,e,f demonstrates the difficulty for EMICs in representing precipitation patterns. Figure $4 \mathrm{~d}$ shows that the distribution of precipitation is too zonal, and there is too much precipitation in coastal areas and too little inland. The bias is smaller, but a non-negligible bias remains in the statistical-dynamical (e.g., Figure eight of Montoya et al. 2005) and quasi-geostrophic (e.g., Goosse et al. 2010) models. For models using primitive equations, Smith (2012) reported that their FAMOUS model had a similar but accentuated precipitation pattern relative to the mother GCM. Bias in precipitation patterns is critical with coupling to terrestrial vegetation models. To solve this problem, Tachiiri et al. (2010) used the spatial pattern of GCM output, extracted from the change in global mean surface air temperature calculated by an EMIC, to run a vegetation model.

\section{Intercomparison of EMICs}

The scope of EMICs is greatly varied. It includes largescale ocean thermohaline circulations, biogeochemical processes, planetary atmospheres, educational use, debugging, and parameter tuning, with focused time scales from decades to several million years (Claussen 2005). Given this variety of model targets and output variables, the design of EMIC model intercomparison projects can be more difficult than that of GCMs/ESMs, in terms of what can or should be compared.

The first EMIC intercomparison project was EMIP$\mathrm{CO}_{2}$ (Petoukhov et al. 2005), in which eight EMICs were involved. The modeled temperature was in relatively good agreement. However, not surprisingly, the spread of zonal precipitation was significant. In IPCC AR4, the same eight EMICs were listed (IPCC 2007), but only half overlapped

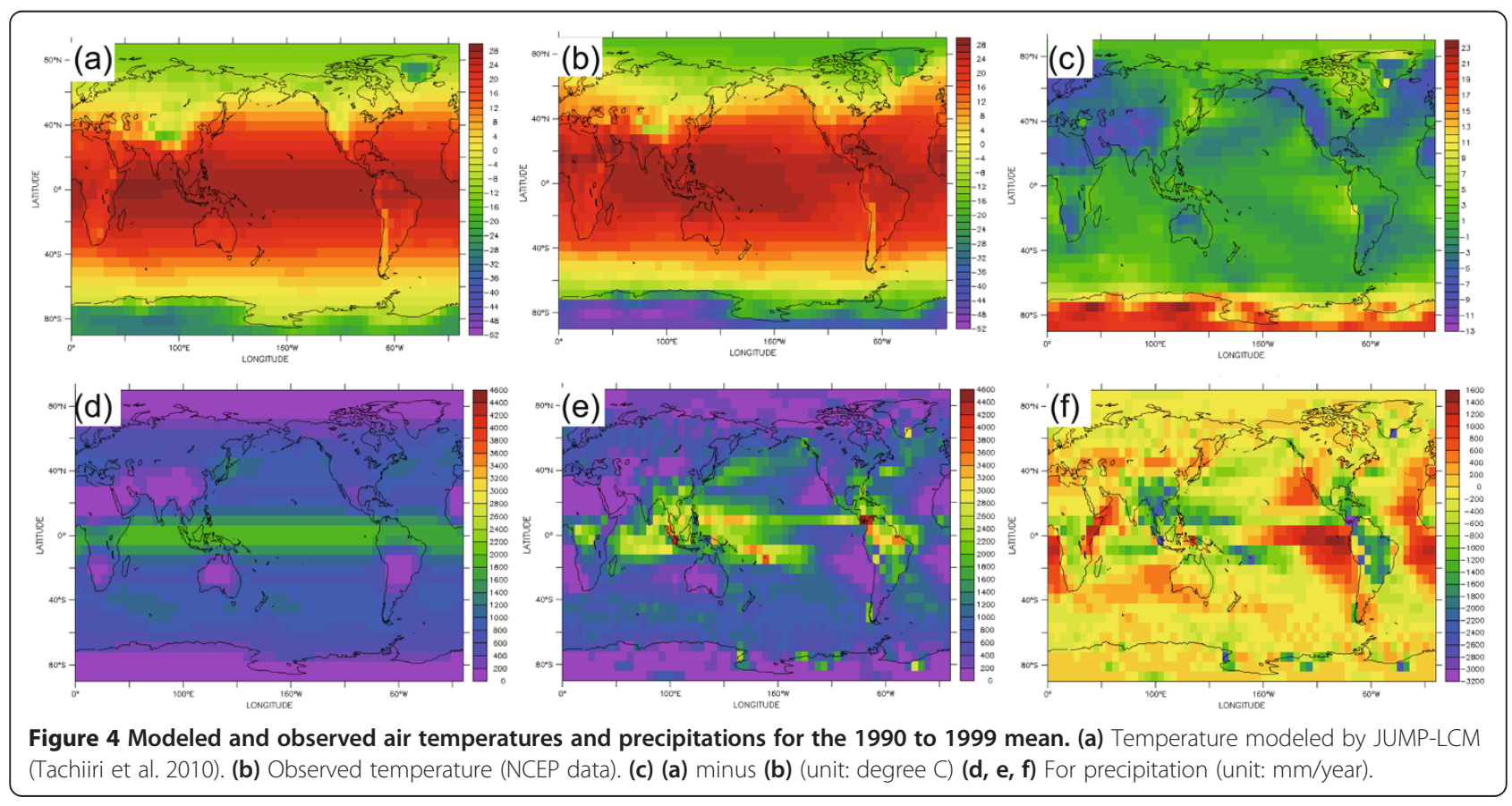


with EMIP- $\mathrm{CO}_{2}$. Brovkin et al. (2006) presented their model intercomparison study results from their interesting experiments on the biogeophysical effects of historical land-cover changes during the last millennium. These results included a $0.13^{\circ} \mathrm{C}$ to $0.25^{\circ} \mathrm{C}$ global mean temperature decrease due to historical deforestation, with significant uncertainty in the zonal mean temperature and evapotranspiration.

In EMIC AR5, project protocol ranged from idealized abrupt and gradual $2 \mathrm{xCO}_{2}$ and $4 \mathrm{xCO}_{2}$, historical (last millennium), to RCP experiments. Eby et al. (2013) stated that similarly to ESMs, land carbon fluxes had much more variation between models than ocean carbon. Comparison of some of their results for EMICs with those for ESMs is presented in Table 1. Equilibrium climate sensitivity and its standard deviation (SD) are similar but slightly less than those of ESMs. Climate-land carbon feedback $\left(\gamma_{\mathrm{L}}\right)$ was similar between EMICs and ESMs, but concentration-land carbon feedback $\left(\beta_{\mathrm{L}}\right)$ and its SD were smaller for EMICs. In contrast, magnitudes (absolute values) of climate- and ocean concentrationcarbon-cycle feedbacks $\left(\beta_{\mathrm{o}}\right.$ and $\left.\gamma_{\mathrm{o}}\right)$ are larger in EMICs. Most interestingly, the SDs of $\beta_{\mathrm{o}}$ and $\gamma_{\mathrm{o}}$ are more than twice those in EMICs relative to ESMs. For the last millennium simulation, there was a tendency for EMICs to underestimate the decline in surface air temperature and $\mathrm{CO}_{2}$ between the Medieval Climate Anomaly and Little Ice Age estimated from paleoclimate reconstructions (although some ESMs used different volcanic aerosol forcing).

Regarding other studies related to EMIC AR5, Weaver et al. (2012) showed that EMIC representations of the strength of the present Atlantic Meridional Overturning Circulation (AMOC) are similar to those of GCMs. In addition, Zickfeld et al. (2013) showed the result of longterm experiments for the future to the year 3000 (forced with RCPs together with their extensions to the year 2300 and then with a fixed atmospheric $\mathrm{CO}_{2}$ concentration and forcing from non- $\mathrm{CO}_{2}$ greenhouse at the year 2300 levels after that), focusing on climate change commitment and reversibility. They presented the spread of temperature rise and cumulative emission for four RCPs and indicated that the meridional overturning circulation (MOC) is weakened temporarily but recovers to near-preindustrial values in most models for RCPs 2.6 to 6.0. The MOC weakening was more persistent for RCP8.5. In comparison to GCMs, the temperature increase projected by EMICs through the end of the twenty-first century was similar in low-concentration scenarios (RCPs 2.6 and 4.5) but significantly lower in RCP 8.5.

\section{Existing and future studies using EMICs}

Weber (2010) discussed existing studies using EMICs for the transient evolution of the climate, the AMOC and hindcasting, assessment of uncertainties, and forecasting. Examples of long-duration experiments include Brovkin et al. (2007), Plattner et al. (2008), Archer et al. (2009), and others dealing with the role of vegetation (Tuenter et al. 2005) and response (Claussen et al. 1999). Studies of the long-term (e.g., up to the year 3000) commitment of the $\mathrm{CO}_{2}$ effect (Plattner et al. 2008; Zickfeld et al. 2013) are included in this type.

Studies using large ensembles, many of which tuned parameters by comparison with observations, include Knutti et al. (2002), Forest et al. (2002), Hargreaves et al. (2004), and Annan et al. (2005). Annan and Hargreaves (2010) carried out experiments of parameter perturbation, including those related to the marine carbon cycle.

For terrestrial ecosystems, Tachiiri et al. (2012) used an EMIC in a parameter perturbation experiment for a vegetation model, identifying parameters that had significant impacts on land carbon uptake under global warming. In another type of carbon cycle-related study, Zickfeld et al. (2011) examined the nonlinearity of climate- and concentration-carbon cycle feedback using UVic-ESM.

Related to the carbon cycle, a relatively new type of study using EMICs addresses climate stabilization, through emission reduction (Matthews and Caldeira 2008) or geoengineering (Brovkin et al. 2009). A policy-oriented study using an EMIC and IAM was presented by Van Vuuren et al. (2008), and Webster et al. (2012) discussed climate policy targets under uncertainty using an EMIC.

An important advantage of EMICs (at least those with an EMBM-type atmosphere) is that we can easily vary climate sensitivity (Plattner et al. 2001; Tachiiri et al. 2010). Through this, we can assess the effect of uncertainty in climate sensitivity on ecosystems and then on the amount of emission following given concentration pathways. An example is Tachiiri et al. (2013) who presented the potential of constraining physical properties of Earth systems using carbon-cycle related observations (in their case, carbon emission). However, they stated that this should be done very carefully because the posterior probability distribution function of physical parameters is sensitive to the characteristics of ecosystem components.

In addition to the traditional use of EMICs (i.e., longterm integration for paleoclimatic studies or perturbed physics ensembles), EMICs are becoming important for assessing uncertainty in global climate-carbon cycle systems and for their application to treating future stabilization pathways. In the near future, given the increase in computational power, some types of EMICs may replace the climatic component of IAMs. Moreover, the increase of primitive equation models for EMIC atmospheres indicates that it may be increasingly difficult to distinguish EMICs from GCMs/ESMs by the processes included. However, this does not mean that 
EMIC importance is declining. On the contrary, this is the route toward a meaningful 'model hierarchy', where EMICs are effectively used for sensitivity tests and tuning parameters with large ensembles to improve the performance of the mother GCM/ESM. Due to this interactive connection between, or hybrid use of, EMICs and GCMs/ ESMs, complementary relationships between these models are expected in the future.

\section{Climate geoengineering}

Although understanding of anthropogenic climate change is steadily deepening, the political response has been slow and inadequate, which has led to a call for more drastic actions such as climate geoengineering. The newly released AR5 of IPCC (2013) has reviewed these schemes in a comprehensive manner for the first time in its history. In this section, we restrict the discussion to scientific aspects of geoengineering, although there are considerable controversies regarding its role in society. Interested readers are referred to the Royal Society (2009) and IPCC (2012) and references therein.

There are useful references on the science of geoengineering, such as Caldeira et al. (2013) and chapters 6 and 7 of IPCC Working Group 1 of AR5. In the following, we focus on the modeling of geoengineering techniques.

\section{Definitions}

According to the IPCC, geoengineering is defined as ' $\mathrm{a}$ broad set of methods and technologies that aim to deliberately alter the climate system in order to alleviate the impacts of climate change' (see the IPCC glossary). This is different from other responses to climate change such as mitigation (reductions of greenhouse gas emissions) or adaptation (moderating the damage by changing societal practice and behavior). Geoengineering is often divided into solar radiation management (SRM) and carbon dioxide removal (CDR). Table 4 lists categories of proposed schemes, based on the classification of the IPCC (2013).

SRM is intended to reflect some incoming solar radiation back to space, e.g., by spraying scattering aerosol particles in the stratosphere (Rasch et al. 2008), brightening clouds (Latham 1990), using a mirror system in space (Angel 2006), or increasing surface albedo (Lenton and Vaughan 2009). There are related schemes, such as a reduction in cloud forcing of cirrus clouds (Mitchell and Finnegan 2009).

CDR (or negative emissions technology, NET) refers to a class of techniques that reduce atmospheric $\mathrm{CO}_{2}$ concentration either by increasing natural carbon sinks or directly removing $\mathrm{CO}_{2}$ via industrial engineering. The proposed schemes include bioenergy with carbon capture and storage (BECCS), direct air capture through chemical engineering, storing biochar in soils, and the
Table 4 Categories of geoengineering proposals, based on IPCC (2013)

\begin{tabular}{ll}
\hline Category & Proposal \\
\hline CDR & Afforestation and reforestation \\
& Bioenergy with carbon capture and storage (BECCS) \\
& Biochar creation and storage in soils \\
& Ocean fertilization by adding nutrients to surface waters \\
& Ocean-enhanced upwelling, bringing more nutrients \\
& to surface waters \\
& Land-based increased weathering \\
& Ocean-based increased weathering \\
& Direct air capture (engineering method) \\
& Space-based methods \\
& Stratospheric aerosol injection \\
& Cloud brightening \\
& Surface albedo changes
\end{tabular}

acceleration of chemical weathering, which in nature absorbs $\mathrm{CO}_{2}$ on a geologic time scale. Because the definition of mitigation covers the enhancement of natural sinks (e.g., afforestation and reforestation), there is some overlap between geoengineering and conventional mitigation. In fact, the simulation of RCP2.6 by an IAM, IMAGE, assumes widespread use of BECCS. Therefore, CDR may not necessarily represent an additional $\mathrm{CO}_{2}$ reduction opportunity. Theoretically, one can achieve removal of non$\mathrm{CO}_{2}$ greenhouse gases, though literature on this is scarce.

Among the many proposed SRM schemes, the two most discussed are stratospheric aerosol injection and cloud brightening. The current understanding of the former is primarily based on climate response to volcanic forcing, and the latter on cloud processes and physics. For the CDR schemes, ocean iron fertilization has historically received great attention. The three schemes in this paragraph are relevant to ESS and modeling.

\section{Characteristics}

Although various techniques are grouped under the rubric of geoengineering, they have vastly different characteristics with respect to effectiveness, environmental risks, and other aspects. As Keith et al. (2010) summarizes, SRM has the following features. Its implementation is usually of low cost and, once initiated, can cool the climate rapidly. However, its ability to counteract climate change is imperfect and cannot offset all its impacts. Further, the science is rudimentary and all aspects of SRM are uncertain.

Take the example of stratospheric aerosol injection. This technique is believed to be capable of counteracting a doubling of $\mathrm{CO}_{2}$ rapidly and cheaply. However, it has side effects, including ozone destruction, slowdown of the global hydrologic cycle, and reduction of electricity 
generation by concentrating solar power. If the injection were ever halted suddenly, it could result in a sudden rise in the global mean surface temperature by unmasking radiative forcing of greenhouse gases. This technique also fails to address ocean acidification.

The characteristics of CDR can be understood by comparison with SRM. CDR is more expensive, slower to affect the carbon cycle, but more reliable because it influences the real culprit of climate change. However, some schemes, especially those that intervene in the ecological system, are certain to have significant side effects. Cost estimates tend to be comparable to or higher than conventional mitigation.

For example, the direct air capture of $\mathrm{CO}_{2}$ is considered to have great potential for atmospheric $\mathrm{CO}_{2}$ reduction. Although technology exists, it is not clear whether it can be operated on an industrial scale because the cost estimate is very uncertain, but it is at least as expensive as conventional mitigation.

\section{Modeling of CDR}

Martin (1990) put forth a hypothesis that iron is the limiting factor in high-nutrient, low-chlorophyll (HNLC) regions such as the Southern Ocean, the equatorial Pacific, and the North Pacific. Since then, about a dozen smallscale $\left(O\left(100 \mathrm{~km}^{2}\right)\right)$ in situ experiments have been conducted (Strong et al. 2009). Because these intervention experiments have vindicated the iron hypothesis, there was growing interest in iron fertilization of oceans for $\mathrm{CO}_{2}$ reduction (see also 'Atmospheric deposition of bioavailable iron in marine ecosystems' section).

Several modeling studies have evaluated ocean fertilization with varying degrees of sophistication. Earlier studies, which used biogeochemical cycle models without the explicit iron cycle, implicitly modeled the effect of iron fertilization, e.g., by depleting near-surface phosphate (Sarmiento and Orr 1991). These studies tended to report optimistic potentials for atmospheric $\mathrm{CO}_{2}$ drawdown, and some reported approximately $100 \mathrm{ppm}$ of $\mathrm{CO}_{2}$ drawdown (Joos et al. 1991; Cao and Caldeira 2010b). As the models improved, however, estimates of the potential were revised downward in most studies. For example, Aumont and Bopp (2006) ran a biogeochemical cycle model with the iron cycle, obtaining a drawdown of 33 ppm (Aumont and Bopp 2006). Similarly, Sarmiento et al. (2010) reported 42 $\mathrm{ppm}$. One reason for such differences is that there are non-iron limiting factors such as silicate and light, and carbon export to the deep ocean can only occur during the growing season (Aumont and Bopp 2006).

In addressing the amount of atmospheric removal, we must consider the 'rebound effect'. When human activities cause $\mathrm{CO}_{2}$ emissions into the atmosphere, only about half remains there, with the rest absorbed by terrestrial and oceanic sinks. When human activity removes $\mathrm{CO}_{2}$ from the atmosphere, the opposite occurs. To reduce the $\mathrm{CO}_{2}$ concentration by $1 \mathrm{ppm}$, for example, one needs to take up an amount of $\mathrm{CO}_{2}$ equivalent to approximately $2 \mathrm{ppm}$ (assuming that the airborne fraction is approximately 0.5 ). This has been termed the rebound effect, and one must be careful about the efficacy of CDR (Cao and Caldeira 2010a).

The ocean fertilization potentials reported above account for the rebound effect from the oceans but exclude the effect from land, thereby overestimating the potential.

Another use of ESMs is to calculate required emission reductions compatible with a certain target RCP. Cumulative emissions compatible with RCP2.6 are estimated at $272 \pm 101 \mathrm{PgC}$ for the period 2012 to 2100 (chapter 6 of IPCC Working Group 1 of AR5, IPCC 2013). Some results suggest that sustained negative emissions, such as those from BECCS, are required.

\section{Modeling of SRM}

Process studies and engineering analyses have indicated that it would be feasible to conduct SRM for canceling a $\mathrm{CO}_{2}$ doubling and that the current cost of implementation is inexpensive, at least for stratospheric aerosol injection. Significant uncertainty remains, however, as to its efficacy of counteracting climate change and its side effects. Modeling can therefore make an important contribution to the evaluation of geoengineering schemes.

The situation of SRM modeling was rudimentary until the advent of the Geoengineering Model Intercomparison Project (GeoMIP), which is related to CMIP5 activities. One of the motivations for this project was the impact of geoengineering on the Asian summer monsoon (Kravitz et al. 2011). Some models implied a substantial decrease in monsoon precipitation, while others suggested the opposite. However, the number of models in the exercise was small and scenario specifications varied, complicating the interpretation. Obviously, a more systematic approach to modeling was needed.

The initial GeoMIP included the following four experiments:

- G1: Cancel the warming from instantaneous $\mathrm{CO}_{2}$ quadrupling with a simultaneous decrease of the solar constant

- G2: Counteract warming from $\mathrm{CO}_{2}$ increase at $1 \%$ per year by steadily reducing the solar constant

- G3: Starting in 2020, offset RCP4.5 forcings by gradually increasing the amount of $\mathrm{SO}_{2}$ or sulfate injected either at the equator or globally

- G4: Starting in 2020, inject a constant amount of $\mathrm{SO}_{2}$ at a rate of $5 \mathrm{Tg}-\mathrm{SO}_{2}$ per year to partially counteract the RCP4.5 forcing. 
This set of experiments had variable scenario complexities to attract many modeling groups, with two experiments focusing on the solar constant and the other two on the injection of sulfates. In CMIP5, most models used an externally specified optical depth to represent volcanic cooling, but models in GeoMIP represent a variety of approaches, from the CMIP5-type approach to directly simulating stratospheric chemistry and aerosols.

In the following, we summarize the 12-model G1 experiment by Kravitz et al. (2013a), which confirmed basic results of previous studies. Twelve fully coupled AOGCMs were included, 11 of which came with a land ecosystem model. The required solar constant reduction was model-dependent, between $3.5 \%$ and $5.0 \%$.

The G1 results show that a reduction of solar insolation can largely offset the temperature changes but leave the polar region warmer (inter-model average $0.8 \mathrm{~K}$ ) and the tropics colder (inter-model average $-0.3 \mathrm{~K}$ ) than preindustrial levels (Figure 5). This is because a reduction of solar insolation by the same fraction led to a large-magnitude reduction in equatorial regions. Similarly, net precipitation (precipitation minus evaporation) induced by quadrupling $\mathrm{CO}_{2}$ could be mostly offset by the reduction of solar insolation, although there was less precipitation in some tropical regions. The tropical precipitation is explained by changes in moist static stability. Quadrupling $\mathrm{CO}_{2}$ increases net primary productivity because of $\mathrm{CO}_{2}$ fertilization effects. In the G1 results, net primary productivity increases a little more, because geoengineering creates an artificial environment in which the $\mathrm{CO}_{2}$ level is elevated and climate change is reduced.

GeoMIP has investigated other topics related to climate geoengineering, such as changes in the hydrologic cycle, extreme events, stratospheric ozone loss, and impacts on agriculture and the cryosphere. The results have been published in a special issue of the Journal of Geophysical Research (Kravitz et al. 2013b). GeoMIP research teams are discussing the next round, which includes experiments on cloud brightening.

\section{Remaining uncertainties}

Although initial evaluations of CDR and SRM techniques are useful, there remain substantial uncertainties in various types of geoengineering method. GeoMIP made great progress in stratospheric aerosol injection and had a plan for cloud brightening as well. Nevertheless, there have been no model intercomparison projects for CDR. If governments and society were to consider

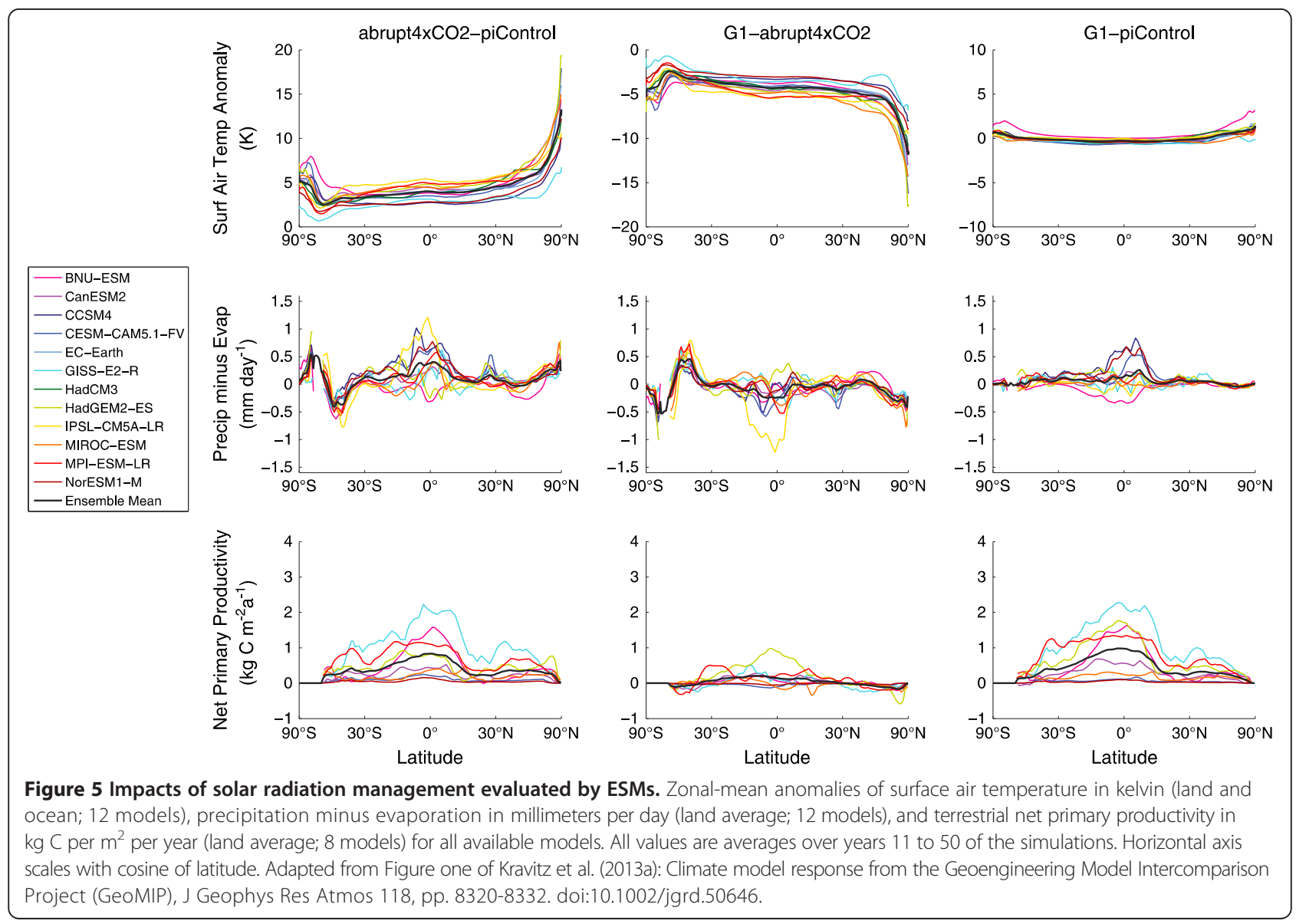


such an option, a more systematic modeling exercise would be needed.

It is important to recognize that there are also substantial uncertainties in CMIP5-class climate models. Driscoll et al. (2012) examined the response to volcanic forcings in CMIP5 models. They identified weaker-thanobservation responses of the stratospheric polar vortex and less warming of Eurasia following a volcanic eruption. This casts doubt on the dynamic responses simulated in GeoMIP.

Similarly, cloud processes are full of uncertainties, and clouds are the key factor in determining climate sensitivity. Better geoengineering simulation requires further development of ESMs.

\section{Ocean $\mathrm{CO}_{2}$ uptake}

\section{Role of oceans as the largest $\mathrm{CO}_{2}$ reservoir}

The ocean, like the terrestrial biosphere, is a major sink of atmospheric $\mathrm{CO}_{2}$. Quantitative analysis shows that the ocean contains about $38,000 \mathrm{PgC}$. This is about 16 times that in the terrestrial biosphere and 60 times that in the preindustrial atmosphere, i.e., at a time before atmospheric $\mathrm{CO}_{2}$ content was altered by the increased burning of fossil fuels from human activities (Post et al. 1990). Therefore, the ocean is the largest carbon reservoir and is critical in determining atmospheric $\mathrm{CO}_{2}$ concentration and thereby the global radiation balance and climate (IPCC 2007). However, the carbon sink from oceanic mixing is slow and requires centuries to convect to the deep ocean (Broecker et al. 1982). Hence, changes in atmospheric $\mathrm{CO}_{2}$ concentration induced by oceanic modulations also occur on century time scales (Broecker and Peng 1986).

\section{Carbon cycle in the ocean}

The carbon cycle in the ocean in terms of biogeochemical processes can be described as follows. When absorbed by seawater, most $\mathrm{CO}_{2}$ turns into bicarbonate ions; this dissolved inorganic form stabilizes 100 times more carbon than $\mathrm{CO}_{2}$ in molecular form. At the sea surface, marine ecosystems such as phytoplankton consume the $\mathrm{CO}_{2}$ through photosynthesis and enhance oceanic $\mathrm{CO}_{2}$ uptake. After the consumption of $\mathrm{CO}_{2}$ by marine organisms, their detritus convects and stabilizes carbon in the middle and deep ocean interior. Since the marine organisms are important, this downward transport of $\mathrm{CO}_{2}$ from the surface to the middle and deep ocean is the so-called ' $\mathrm{CO}_{2}$ capture and storage (CCS)' and 'biological pump' (Volk and Hoffert 1985; Longhurst and Harrison 1989).

Takahashi et al. $(2002,2009)$ analyzed global distributions of monthly and annual net sea-air $\mathrm{CO}_{2}$ flux based on nearly a million measurements of the sea surface partial pressure of $\mathrm{CO}_{2}\left(\mathrm{pCO}_{2}\right)$ since late the 1950s. They estimated the annual net uptake of $\mathrm{CO}_{2}$ by the global oceans at approximately 2.2 PgC. Strong $\mathrm{CO}_{2}$ sink areas were seen in the transition zone between the subtropical gyre and subpolar waters, around $60^{\circ} \mathrm{S}$ to $40^{\circ} \mathrm{S}$ in the Southern Ocean and $40^{\circ} \mathrm{N}$ to $60^{\circ} \mathrm{N}$ in the North Atlantic, owing to low $\mathrm{pCO}_{2}$ waters formed by juxtaposition of the cooling of warm waters with biological drawdown of $\mathrm{pCO}_{2}$ in the nutrient-rich subpolar waters. Nevertheless, the most intense $\mathrm{CO}_{2}$ source areas are the eastern equatorial Pacific and northwestern Arabian Sea. The tropical Atlantic and Indian oceans and northwestern subarctic Pacific are also prominent source areas. During La Niña events, the equatorial Pacific could be a stronger $\mathrm{CO}_{2}$ source, in response to local upwelling of $\mathrm{CO}_{2}$-rich waters (Feely et al. 1999).

\section{Anthropogenic $\mathrm{CO}_{2}$ uptake}

Sabine et al. (2004) estimated a global oceanic anthropogenic $\mathrm{CO}_{2}$ sink for the period of 1800 to 1994 for 99 to $137 \mathrm{PgC}$ based on the most accurate and comprehensive measurements of inorganic carbon, oxygen, nutrients, and chlorofluorocarbons. These measurements were made in the 1990s during two international ocean research programs, the World Ocean Circulation Experiment (WOCE) and Joint Global Ocean Flux Study (JGOFS). The oceanic sink accounted for approximately $48 \%$ of total fossil-fuel and cement-manufacturing emissions for the about 200 years since the beginning of the industrial period. This could potentially increase atmospheric $\mathrm{CO}_{2}$ to approximately $55 \mathrm{ppm}$ higher than the present level, if released from the ocean.

In contrast to the oceanic $\mathrm{CO}_{2}$ sink, the terrestrial biosphere has been a net source of $\mathrm{CO}_{2}$ to the atmosphere of about 11 to $67 \mathrm{PgC}$, because $\mathrm{CO}_{2}$ emissions from landuse change (100 to $180 \mathrm{PgC}$ ) overwhelm the $\mathrm{CO}_{2}$ uptake of the terrestrial biosphere (61 to $141 \mathrm{PgC}$ ) (Sabine et al. 2004). High anthropogenic $\mathrm{CO}_{2}$ concentrations are found in the North Atlantic and between $50^{\circ} \mathrm{S}$ and $14^{\circ} \mathrm{S}$, representing $23 \%$ and $40 \%$, respectively, of the global oceanic anthropogenic $\mathrm{CO}_{2}$. About $30 \%$ of the anthropogenic $\mathrm{CO}_{2}$ is found at depths shallower than $200 \mathrm{~m}$. Nearly $50 \%$ is at depths above $400 \mathrm{~m}$ and is rarely observed below $1,000 \mathrm{~m}$.

\section{The Southern Ocean}

As a major sink of atmospheric $\mathrm{CO}_{2}$, the Southern Ocean absorbs $\mathrm{CO}_{2}$ at an annual rate of about $1.5 \mathrm{PgC}$ (IPCC 2007), although this rate has been decreasing. Recent trends in the Southern Hemisphere tropospheric circulation can be interpreted as a bias toward highindex polarity of the Southern Annular Mode (SAM), with stronger westerly flow encircling the polar cap (Thompson and Solomon 2002). The largest and most significant tropospheric trends can be traced to recent variations in the lower stratospheric polar vortex, which are largely attributed to photochemical ozone losses. 
Surface cooling over most of Antarctica is also associated with shifts in the SAM contributed by the Antarctic ozone depletion and increasing greenhouse gases (Shindell and Schmidt 2004).

Based on observed atmospheric $\mathrm{CO}_{2}$ concentration and an inverse method, Le Quéré et al. (2007) estimated that the Southern Ocean sink of $\mathrm{CO}_{2}$ south of $45^{\circ} \mathrm{S}$ weakened between 1981 and 2004 by $0.08 \mathrm{PgC}$ per decade, relative to the trend expected from the large increase in atmospheric $\mathrm{CO}_{2}$. They attributed this weakening to the observed increase in Southern Ocean winds resulting from human activities, which is projected to continue in the future. Consequences include a reduction in the efficiency of the Southern Ocean sink of $\mathrm{CO}_{2}$ in the short term (approximately 25 years) and possibly greater stabilization of atmospheric $\mathrm{CO}_{2}$ on a multi-century scale (Figure 6).

\section{Atmospheric deposition of bioavailable iron in marine ecosystems}

Iron $(\mathrm{Fe})$ is an essential micronutrient for primary production in marine ecosystems (Jickells et al. 2005; Uematsu 2013; see also the 'Modeling of CDR' section). Since most aquatic organisms can take up iron only in dissolved form, the amount of soluble iron is of major importance (Raiswell and Canfield 2012). The majority of iron is delivered from arid and semiarid regions to the open ocean but is mainly in insoluble form (Mahowald et al. 2009). Insoluble iron oxides in soils can be transformed

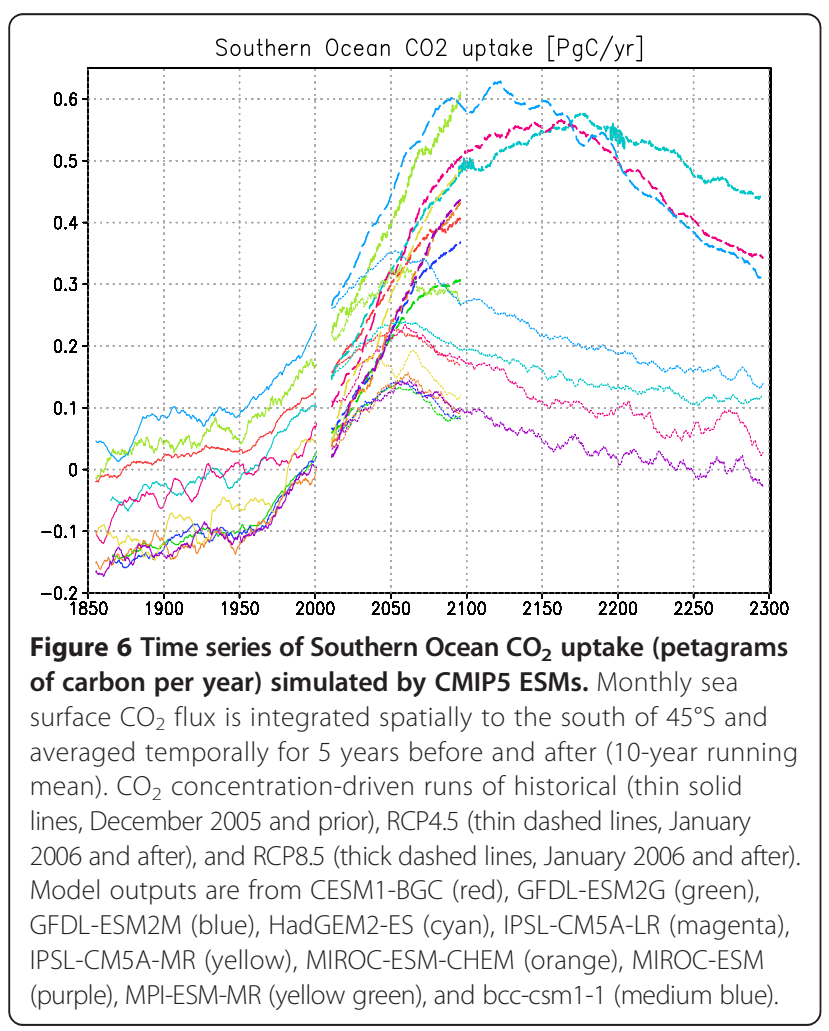

to soluble iron in mineral aerosols via acid processing, photochemical reduction, and ligand-promoted iron dissolution during cycling of dust particles between cloud and aerosol water (Shi et al. 2012). In addition to iron in the form of aqueous species, aerosols supply iron in colloidal or nanoparticulate forms that can be transformed into soluble iron in seawater (Baker and Croot 2010). Compared with mineral aerosols, aerosols from combustion processes contribute to high iron solubility observed over oceans (Sholkovitz et al. 2012). In this review, we focus on global atmospheric modeling studies of soluble iron input to the oceans. This builds on a number of earlier reviews of iron in the biogeochemical cycle (Jickells et al. 2005; Mahowald et al. 2009; Baker and Croot 2010; Raiswell and Canfield 2012; Shi et al. 2012; Sholkovitz et al. 2012).

\section{Global atmospheric modeling studies}

The atmospheric deposition of iron in the oceans has been extensively examined in global modeling studies, and the predicted total iron deposition is in better agreement between various studies than in soluble iron deposition, owing to large uncertainties in aerosol iron solubility (i.e., the percentage of total aerosol iron that is soluble in water) (Table 5). Conventionally, global bioavailable iron deposition has been estimated with prescribed iron solubility in aerosols at $1 \%$ to $2 \%$ (Jickells et al. 2005). To estimate the effects of the atmospheric processing of dust on iron solubility in a global transport model of mineral aerosols, Hand et al. (2004) used a soluble decay lifetime of 300 days to represent the conversion of insoluble iron to soluble iron at 20\% iron solubility for dust transport across the Atlantic Ocean. Similarly, some global transport models use parameterizations of iron dissolution rates in mineral aerosols to fit observations of iron solubility (Luo et al. 2005; Fan et al. 2006; Han et al. 2012). However, elevated iron solubility values have been measured for bulk aerosol samples when combustion aerosols are captured on the filters (Chuang et al. 2005; Guieu et al. 2005; Sedwick et al. 2007). Thus, the fitted iron dissolution rate of mineral dust with observed iron solubility overestimates solubility of the mineral dust in models. Fast solution methods for atmospheric processing are useful when investigating factors affecting ecosystem and climate changes because atmospheric chemistry is the most time-consuming part of the calculations in ESMs (Ito and Kawamiya 2010). To increase accuracy and reduce uncertainty in the models, however, it is essential that a simplified model give results that are equivalent to more complete processbased mechanisms.

The chemical and physical properties of combustion and dust aerosols are different (Siefert et al. 1999; Desboeufs et al. 2005), and thus it is important to 


$\begin{aligned} & \text { Table } \mathbf{5} \text { Global iron (Fe) and soluble Fe deposition on the } \\
& \text { oceans and fractional Fe solubility }\end{aligned}$
\begin{tabular}{lccc}
\hline Study & $\begin{array}{c}\text { Fe } \\
\text { (Tg year- }{ }^{-1} \text { ) }\end{array}$ & $\begin{array}{c}\text { Soluble Fe } \\
\text { (Tg year- }^{-1} \text { ) }\end{array}$ & Fe solubility (\%) \\
\hline Fan et al. (2006) & 21 & 2.3 & 11 \\
Han et al. (2012) & 11 & 0.47 & 4.1 \\
Ito et al. (2012) & 15 & 0.29 & 1.9 \\
Ito (2013) & 16 & 0.45 & 2.8 \\
Ito and Xu (2014) & 12 & 0.35 & 2.8 \\
Jickells et al. (2005) & 16 & 0.16 to 0.32 & 1 to 2 \\
Johnson and & $18^{\text {a }}$ & 0.26 & 1.4 \\
Meskhidze (2013) & & & 3.3 to 15 \\
Luo et al. (2005) & $11^{\text {b }}$ & 0.36 to 1.6 & 1.9 \\
Luo et al. (2008) & $11^{\text {b }}$ & $0.21^{\text {b }}$ & 3.1 \\
Luo and Gao (2010) & $11^{\text {b }}$ & 0.34 & \\
\hline
\end{tabular}

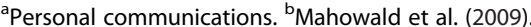

understand the influence of those properties on iron solubility. Luo et al. (2008) compiled emission factors for iron in combustion sources such as coal combustion and biomass burning. Their model results suggested that combustion sources of iron contribute a significant amount of soluble iron deposition over oceans downwind of industrialized and biomass burning regions, because of high iron solubility. It was also pointed out that biomass burning (e.g., savanna and forest fires) is an important source of soluble iron in areas with low levels of atmospheric pollutants and mineral dust (Ito 2011, 2012). However, including combustion aerosols in global models did not show any significant improvement in comparison with observations of iron solubility (Luo et al. 2008; Ito 2012). By making a distinction for iron solubility between the various sources of iron in combustion aerosols, Ito (2013) suggested that atmospheric models improve the simulation of high iron solubility $(>10 \%)$ at low iron loading $(<100 \mathrm{ng}$ $\mathrm{m}^{-3}$ ) over the open ocean (Figure 7). The main mechanisms leading to enhanced iron solubility are the high iron solubility associated with oil combustion aerosols from shipping and the iron mobilization of mineral dust. The former process can produce high iron solubility at low iron loading. The latter process can transform waterinsoluble iron in soils to soluble forms (e.g., ferrihydrite colloids, nanoparticles, and aqueous species) during long-range atmospheric transport. The model predicts narrower variability of iron solubility for large mass concentrations (100 to $10,000 \mathrm{ng} \mathrm{m}^{-3}$ ) than observed, under a variety of conditions (Figure 7). These results suggest that achieving a more accurate simulation of iron solubility $(0.1 \%$ to $10 \%)$ for a wide range of mass concentrations (10 to $10,000 \mathrm{ng} \mathrm{m}^{-3}$ ) has important implications for the range of model-based estimates of soluble iron deposition and its response to environmental change.
Mineral dissolution rates depend on several kinetic parameters (e.g., temperature, $\mathrm{pH}$, and degree of solution saturation) (Zhuang et al. 1992). Based on laboratory experiments for iron oxides (i.e., hematite), Meskhidze et al. (2005) used the parameterization of proton-promoted acid mobilization (Lasaga et al. 1994) for mineral aerosols in a Lagrangian box model, which involves a thermodynamic equilibrium module to estimate acidity in the aqueous phase of hygroscopic particles. A chemical transport model that implemented the iron dissolution scheme for dust aerosols suggested significant acid mobilization of iron in the East Asia outflow over the North Pacific, because aerosol water becomes very acidic $(\mathrm{pH}<2)$ due to air pollution (Solmon et al. 2009). However, such a highly acidic condition is very rare for mineral dust in the atmosphere because alkaline gases and minerals neutralize the acidic species in most cases (Ito and Feng 2010; Johnson et al. 2010).

It is obvious that modeling must follow experimental and mechanistic understanding. Laboratory experiments for different dust source samples suggest much faster iron dissolution rates than those used in the explicit dissolution scheme (Mackie et al. 2005; Shi et al. 2011a). The iron mobilization model is based on the assumption that the mineral dissolution behaves similarly to simple iron oxides under acidic conditions. However, mineral dust is composed of variable amounts of clay minerals (e.g., illite, kaolinite, and smectite), carbonates (e.g., calcite), quartz, oxides (e.g., hematite), feldspars, and evaporite minerals (e.g., gypsum) (Claquin et al. 1999; Nickovic et al. 2012). Thus, aerosol mineralogy, especially the chemical form of iron in aerosols, can be a critical factor for iron dissolution (Cwiertny et al. 2008; Journet et al. 2008; Shi et al. 2011b). Further, the dissolution of iron oxides depends critically on particle size (Kraemer 2004; Rubasinghege et al. 2010; Lanzl et al. 2012). Based on laboratory experiments for specific mineral samples (Journet et al. 2008; Shi et al. 2011b) and soil and dust samples (Mackie et al. 2005; Shi et al. 2011a), Ito and $\mathrm{Xu}$ (2014) improved the treatment of iron in mineral dust and its dissolution scheme under acidic conditions to emulate dissolution curves for African, Asian, and Australian samples. This more complete understanding of the processes controlling iron dissolution improves the predictive capability for the wide variability of iron solubility ( $1 \%$ to $10 \%$ ) over the oceans of the Northern Hemisphere (Ito and Xu 2014).

\section{Future outlook: interactions of mineral aerosols with organics}

To facilitate more accurate parameterization of iron dissolution in atmospheric water, it is desirable that laboratory conditions be as representative as possible of ambient conditions. Low molecular weight dicarboxylic acids (e.g., 

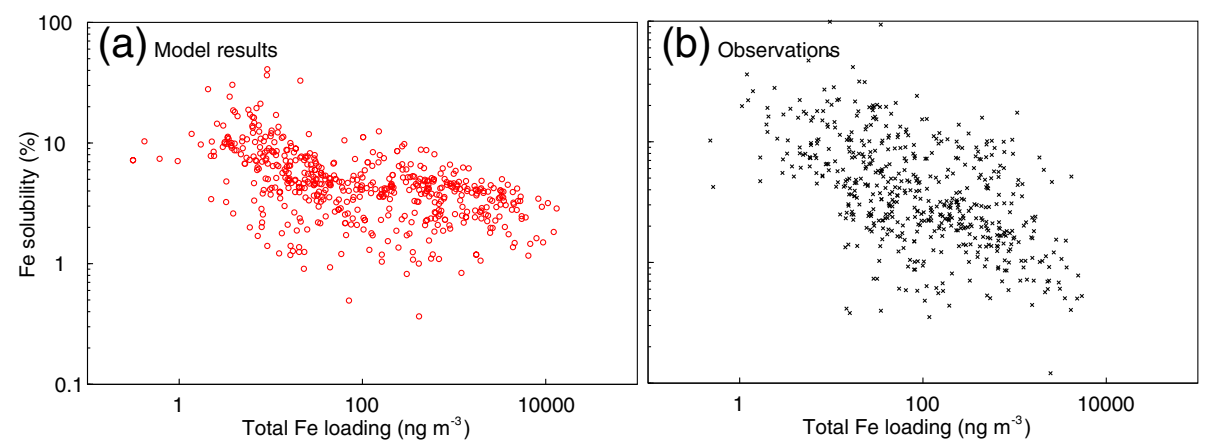

Figure 7 Atmospheric loading of total aerosol iron $\left(\mathrm{ng} \mathrm{m}^{-3}\right.$ ) versus percent of soluble iron in total iron. (a) Model results (red circles) of Ito (2013) and (b) observations (black crosses) over the oceans from 2001 to 2006. Aerosol iron solubility is plotted against iron loading on a log 10 scale to emphasize values at low solubility in Figure eight (a) and (b) of Ito (2013).

oxalic acids) are recognized as ubiquitous aerosol constituents in the troposphere (Kawamura 2006; Ervens et al. 2011). In recent years, increased attention has been given to the organic acids for promoting iron dissolution in global models (Luo et al. 2005; Luo and Gao 2010; Johnson and Meskhidze 2013). To estimate the oxalate concentration in mineral dust, Luo and Gao (2010) used the molar ratio of oxalate to sulfate (2\%) based on observations ranging from $0.46 \%$ to $5 \%$ ( $\mathrm{Yu}$ et al. 2005). The observed oxalate refers to the sum of oxalic acid and oxalate in aerosol particles, since ion chromatography allows quantification of oxalate independent of its chemical form. The positive relationship between oxalate and sulfate is likely due to a common dominant formation pathway in cloud droplets (Yao et al. 2002; Yu et al. 2005). In cloud water, water-soluble organic compounds dissolve into the aqueous phase and form oxalic acids through oxidation (Myriokefalitakis et al. 2011; Liu et al. 2012; Lin et al. 2014). Since iron dissolves slowly from mineral soils in cloud water conditions (up to $0.26 \%$ of iron solubility after 60 min contact time; Paris et al. 2011), the effect of oxalatepromoted dissolution on dissolved iron concentrations in cloud water is not large enough to explain the variability of iron solubility in atmospheric aerosols ( $0.1 \%$ to $10 \%)$.

Furthermore, strong complexation of iron with organic compounds (e.g., humic substances) has been observed in rainwater (e.g., Kieber et al. 2003; Cheize et al. 2012). Furukawa and Takahashi (2011) showed that most of the oxalate is present as stable complexes in aerosol particles. These results suggest that iron in cloud water and oxalate in aerosol might not be readily available for iron-oxalate complexes but present as more stable forms. Because of a lack of knowledge of specific organic compounds and their formation rates in cloud and aerosol water, it is premature to draw conclusions regarding the nature of iron-organic complexes (Deguillaume et al. 2005; Willey et al. 2012). Further research on laboratory and field measurements are required to investigate the major formation process of oxalic acid and its effect on iron dissolution in mineral aerosols. Atmospheric chemical transport models are useful to validate the laboratory results for their application to ambient atmospheric conditions.

\section{Conclusions}

The ESS concept has existed for a relatively long time, but its urgent need has only been met over the last decade, being partially realized by ESMs. This is perhaps why scientists remain hesitant to acknowledge this new field as a discipline. Another reason may be that while other new scientific fields have often defined themselves by restricting subjects and methods and decomposing their subjects into components at finer spatial and temporal scales, ESS and its modeling have, by nature, an inclination toward widening of subjects and integration of existing paradigms to investigate component interactions spatially and temporally.

The authors' view is that ESS should be regarded as a framework of thought rather than an established discipline. This interpretation is perhaps more readily acceptable to many scientists. However, another question arises as to whether ESS is really a 'specialty' worth spending a scientist's entire lifetime (or a considerable portion thereof). However, given the current situation in which responding to global change is a pressing mission for earth science as a whole, there is an obvious need for a 'bridge' to connect ever-deepening traditional disciplines, thereby enabling a heuristic and holistic approach to interactions among subsystems of the global environment. It would be invaluable for Earth system scientists to create and develop a common mindset that commands a bird'seye view of relevant fields of earth science and possibly social science. The authors believe that modeling will continue to contribute to cooperative growth of diversifying disciplines and expanding ESS. 


\section{Abbreviations}

BECCS: bioenergy with carbon capture and storage; CDR: carbon dioxide removal; CMIP5: 5th phase of Coupled Model Intercomparison Project; CMIP6: 6th phase of Coupled Model Intercomparison Project; EMBM: cnergy moisture balance model; EMIC: Earth system models of intermediate complexity; ESS: Earth system science; FAO: Food and Agriculture Organization of the United Nations; GCM: general circulation models; HNLC: high-nutrient, low-chlorophyll; HYDE: History Database of the Global Environment; IAMs: integrated assessment models; IPCC: Intergovernmental Panel on Climate Change; JAMSTEC: Japan Agency for Marine-Earth Science and Technology; LUC: land-use change; LUCID: Land-Use and Climate, Identification of Robust Impacts; MIROC-ESM: Model for Interdisciplinary Research on Climate, Earth System Model; NET: negative emissions technology; NIES: National Institute for Environmental Studies; RCP: representative concentration pathway; SRM: solar radiation management; WCRP: World Climate Research Programme.

\section{Competing interests}

The authors declare that they have no competing interests.

\section{Authors' contributions}

MK designed the outline of this paper and wrote the 'Introduction' and 'Conclusions' sections. TH was responsible for the 'Introduction' and 'Nitrogen cycle' sections and compiled the entire document. MW, EK, and KT contributed to the 'Ocean acidification,' 'Land-use and land-cover change,' and 'Earth system models of intermediate complexity' sections, respectively. MS and SW contributed to the 'Climate geoengineering' section. $\mathrm{HO}$ and $\mathrm{Al}$ were respectively responsible for the sections 'Ocean $\mathrm{CO}_{2}$ uptake' and 'Atmospheric deposition of bioavailable iron in marine ecosystems'. All authors read and approved the final manuscript.

\section{Acknowledgements}

This work was supported by SOSEl, the 'Program for Risk Information on Climate Change', by the Ministry of Education, Culture, Sports, Science and Technology of Japan. The Earth Simulator and JAMSTEC Super Computing System were used for outputs introduced in the article. The authors are grateful to Kohei Ishihara who helped with CMIP5 data collection and server management. The author of the 'Earth system models of intermediate complexity' section thanks Dr. A. Oka and Dr. M. Yoshimori of the Atmosphere and Ocean Research Institute (AORI) of the University of Tokyo for their helpful comments on an earlier version of the manuscript. Thanks are also due to Dr. T. T. Sakamoto (AORI) for his comments on Table 2.

\section{Author details}

${ }^{1}$ Yokohama Institute for Earth Sciences, Japan Agency for Marine-Earth Science and Technology, 3173-25 Showa-machi, Kanazawa-ku, Yokohama 236-0001, Japan. ${ }^{2}$ Center for Global Environmental Research, National Institute for Environmental Studies, 16-2 Onogawa, Tsukuba, Ibaraki 305-8506, Japan. ${ }^{3}$ The Institute of Applied Energy (IAE), Shimbashi SY Bldg., 1-14-2 Nishi-Shimbashi 1-Chome, Minato-ku, Tokyo 105-0003, Japan. ${ }^{4}$ Policy Alternatives Research Institute, University of Tokyo, 7-3-1, Hongo, Bunkyo-ku, Tokyo 113-0033, Japan.

Received: 6 August 2014 Accepted: 17 November 2014 Published online: 18 December 2014

\section{References}

Anav A, Friedlingstein P, Kidston M, Bopp L, Ciais P, Cox P, Jones C, Jung M, Myneni R, Zhu Z (2013) Evaluating the land and ocean components of the global carbon cycle in the CMIP5 Earth system models. J Climate 26(18):6801-6843

Andrews T, Gregory JM, Webb MJ, Taylor KE (2012) Forcing, feedbacks and climate sensitivity in CMIP5 coupled atmosphere-ocean climate models. Geophys Res Lett 39(9):L09712, doi:10.1029/2012GL051607

Angel R (2006) Feasibility of cooling the Earth with a cloud of small spacecraft near the inner Lagrange point (L1). P Natl Acad Sci 103(46):17184-17189

Annan J, Hargreaves J (2010) Efficient identification of ocean thermodynamics in a physical/biogeochemical ocean model with an iterative importance sampling method. Ocean Model 32(3):205-215
Annan J, Hargreaves J, Edwards N, Marsh R (2005) Parameter estimation in an intermediate complexity Earth system model using an ensemble Kalman filter. Ocean Model 8(1):135-154

Archer D, Eby M, Brovkin V, Ridgwell A, Cao L, Mikolajewicz U, Caldeira K, Matsumoto K, Munhoven G, Montenegro A (2009) Atmospheric lifetime of fossil fuel carbon dioxide. Annu Rev Earth PI Sc 37(1):117-134

Arora VK, Boer GJ, Friedlingstein P, Eby M, Jones CD, Christian JR, Bonan G, Bopp L, Brovkin V, Cadule P, Hajima T, Ilyina T, Lindsay K, Tjiputra JF, Wu T (2013) Carbon-concentration and carbon-climate feedbacks in CMIP5 Earth system models. J Climate 26(15):5289-5314, doi:10.1175/jcli-d-12-00494.1

Artioli Y, Blackford JC, Butenschon M, Holt JT, Wakelin SL, Thomas H, Borges AV, Allen Jl (2012) The carbonate system in the North Sea: sensitivity and model validation. J Marine Syst 102:1-13, doi:10.1016/J. Jmarsys.2012.04.006

Asrar G, Busalacchi A, Hurrell J (2012) Developing plans and priorities for climate science in service to society. Eos Trans AGU 93(12):128

Aumont O, Bopp L (2006) Globalizing results from ocean in situ iron fertilization studies. Global Biogeochem Cy 20(2):GB2017, doi:10.1029/2005GB002591

Baker A, Croot P (2010) Atmospheric and marine controls on aerosol iron solubility in seawater. Mar Chem 120(1):4-13

Bala G, Caldeira K, Wickett M, Phillips T, Lobell D, Delire C, Mirin A (2007) Combined climate and carbon-cycle effects of large-scale deforestation. P Natl Acad Sci 104(16):6550-6555

Bates NR (2007) Interannual variability of the oceanic $\mathrm{CO}_{2}$ sink in the subtropical gyre of the North Atlantic Ocean over the last 2 decades. J Geophys Res-Oceans 112(C9):Artn C09013, doi:10.1029/2006jc003759

Bates NR, Peters AJ (2007) The contribution of atmospheric acid deposition to ocean acidification in the subtropical North Atlantic Ocean. Mar Chem 107 (4):547-558, doi:10.1016/J.Marchem.2007.08.002

Bodirsky B, Popp A, Weindl I, Dietrich J, Rolinski S, Scheiffele L, Schmitz C, Lotze-Campen $\mathrm{H}$ (2012) $\mathrm{N}_{2} \mathrm{O}$ emissions from the global agricultural nitrogen cycle-current state and future scenarios. Biogeosciences 9(10):4169-4197

Bonan GB (2008) Forests and climate change: forcings, feedbacks, and the climate benefits of forests. Science 320(5882):1444-1449

Bonan GB, Levis S (2010) Quantifying carbon-nitrogen feedbacks in the Community Land Model (CLM4). Geophys Res Lett 37:L07401, doi:10.1029/2010gl042430

Bouwman A, Van Drecht G, Van der Hoek K (2005) Global and regional surface nitrogen balances in intensive agricultural production systems for the period

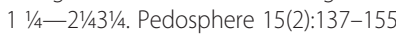

Boysen LR, Brovkin V, Arora VK, Cadule P, de Noblet-Ducoudré N, Kato E, Pongratz J, Gayler V (2014) Global and regional effects of land-use change on climate in 21 st century simulations with interactive carbon cycle. Earth Sys Dynam Discuss 5:443-472

Broecker WS, Peng TH, Beng Z (1982) Tracers in the sea. Lamont-Doherty Geological Observatory, Columbia University, New York

Broecker WS, Peng TH (1986) Carbon cycle; 1985 glacial to interglacial changes in the operation of the global carbon cycle. Radiocarbon 28(2A):309-327

Broecker W, Clark E (2001) A dramatic Atlantic dissolution event at the onset of the last glaciation. Geochem Geophy Geosy 2(11):2001GC000185, doi:10.1029/2001GC000185

Brovkin V, Boysen L, Arora V, Boisier J, Cadule P, Chini L, Claussen M, Friedlingstein P, Gayler V, Van Den Hurk B (2013) Effect of anthropogenic land-use and land-cover changes on climate and land carbon storage in CMIP5 projections for the twenty-first century. J Climate 26(18):6859-6881

Brovkin V, Claussen M, Driesschaert E, Fichefet T, Kicklighter D, Loutre M-F, Matthews H, Ramankutty N, Schaeffer M, Sokolov A (2006) Biogeophysical effects of historical land cover changes simulated by six Earth system models of intermediate complexity. Clim Dynam 26(6):587-600

Brovkin V, Ganopolski A, Archer D, Rahmstorf S (2007) Lowering of glacial atmospheric $\mathrm{CO}_{2}$ in response to changes in oceanic circulation and marine biogeochemistry. Paleoceanography 22(4):PA4202

Brovkin V, Petoukhov V, Claussen M, Bauer E, Archer D, Jaeger C (2009) Geoengineering climate by stratospheric sulfur injections: Earth system vulnerability to technological failure. Climatic Change 92(3-4):243-259

Bruinsma J (2009) The resource outlook to 2050: by how much do land, water, and crop yields need to increase by 2050? FAO Expert meeting on 'How to feed the world in 2050': 24-26 June 2009. FAO, Rome

Budyko MI (1969) The effect of solar radiation variations on the climate of the earth. Tellus 21(5):611-619

Cai WJ, Hu XP, Huang WJ, Murrell MC, Lehrter JC, Lohrenz SE, Chou WC, Zhai WD, Hollibaugh JT, Wang YC, Zhao PS, Guo XH, Gundersen K, Dai MH, Gong 
GC (2011) Acidification of subsurface coastal waters enhanced by eutrophication. Nat Geosci 4(11):766-770, doi:10.1038/Ngeo1297

Caldeira K, Bala G, Cao L (2013) The science of geoengineering. Annu Rev Earth PI Sc 41:231-256

Caldeira K, Wickett ME (2003) Oceanography: anthropogenic carbon and ocean pH. Nature 425(6956):365, doi:10.1038/425365a

Caldeira K, Wickett ME (2005) Ocean model predictions of chemistry changes from carbon dioxide emissions to the atmosphere and ocean. J Geophys Res-Oceans 110(C9), doi:10.1029/2004jc002671

Canfield DE, Glazer AN, Falkowski PG (2010) The evolution and future of Earth's nitrogen cycle. Science 330(6001):192-196, doi:10.1126/science.1186120

Cao L, Caldeira K (2010a) Atmospheric carbon dioxide removal: long-term consequences and commitment. Environ Res Lett 5(2):024011

Cao L, Caldeira K (2010b) Can ocean iron fertilization mitigate ocean acidification? Climatic Change 99(1-2):303-311

Cheize M, Sarthou G, Croot PL, Bucciarelli E, Baudoux AC, Baker AR (2012) Iron organic speciation determination in rainwater using cathodic stripping voltammetry. Analytica Chimica Acta 736:45-54

Chuang P, Duvall R, Shafer M, Schauer J (2005) The origin of water soluble particulate iron in the Asian atmospheric outflow. Geophys Res Lett 32(7):L07813

Claquin T, Schulz M, Balkanski Y (1999) Modeling the mineralogy of atmospheric dust sources. J Geophys Res 104(D18):22243-22256

Claussen M (2005) Table of EMICs: Earth system models of intermediate complexity. Institut für Klimafolgenforschung, Potsdam

Claussen M, Brovkin V, Ganopolski A (2001) Biogeophysical versus biogeochemical feedbacks of large-scale land cover change. Geophys Res Lett 28(6):1011-1014

Claussen M, Kubatzki C, Brovkin V, Ganopolski A, Hoelzmann P, Pachur HJ (1999) Simulation of an abrupt change in Saharan vegetation in the Mid-Holocene. Geophys Res Lett 26(14):2037-2040

Claussen M, Mysak LA, Weaver AJ, Crucifix M, Fichefet T, Loutre MF, Weber SL, Alcamo J, Alexeev VA, Berger A, Calov R, Ganopolski A, Goosse H, Lohmann G, Lunkeit F, Mokhov II, Petoukhov V, Stone P, Wang Z (2002) Earth system models of intermediate complexity: closing the gap in the spectrum of climate system models. Clim Dynam 18(7):579-586, doi:10.1007/S00382-001-0200-1

Cox PM, Betts RA, Jones CD, Spall SA, Totterdell IJ (2000) Acceleration of global warming due to carbon-cycle feedbacks in a coupled climate model. Nature 408(6809):184-187, doi:10.1038/35041539

Cwiertny DM, Young MA, Grassian VH (2008) Chemistry and photochemistry of mineral dust aerosol. Annu Rev Phys Chem 59:27-51

Davin EL, de Noblet-Ducoudré N (2010) Climatic impact of global-scale deforestation: radiative versus nonradiative processes. J Climate 23(1):97-112

Deguillaume L, Leriche M, Desboeufs K, Mailhot G, George C, Chaumerliac N (2005) Transition metals in atmospheric liquid phases: sources, reactivity, and sensitivity parameters. Chem Rev 105:3388-3431

Desboeufs K, Sofikitis A, Losno R, Colin J, Ausset P (2005) Dissolution and solubility of trace metals from natural and anthropogenic aerosol particulate matter. Chemosphere 58(2):195-203

Doney SC, Fabry VJ, Feely RA, Kleypas JA (2009) Ocean acidification: the other $\mathrm{CO}_{2}$ problem. Ann Rev Mar Sci 1:169-192, doi:10.1146/annurev.marine.010908.163834

Dore JE, Lukas R, Sadler DW, Church MJ, Karl DM (2009) Physical and biogeochemical modulation of ocean acidification in the central North Pacific. Proc Natl Acad Sci USA 106(30):12235-12240, doi:10.1073/pnas.0906044106

Driesschaert E (2005) Climate change over the next millennia using LOVECLIM, a new Earth system model including the polar ice sheets. In: PhD Thesis. Université Catholique de Louvain, Louvain-la-Neuve, p 214, [http://dial.academielouvain.be/

Driscoll S, Bozzo A, Gray L, Robock A, Stenchikov G (2012) Coupled Model Intercomparison Project 5 (CMIP5) simulations of climate following volcanic eruptions. J Geophys Res-Atmospheres 117:D17105, doi:10.1029/2012jd017607

Eby M, Weaver AJ, Alexander K, Zickfeld K, Abe-Ouchi A, Cimatoribus AA, Crespin E, Drijfhout SS, Edwards NR, Eliseev AV, Feulner G, Fichefet T, Forest CE, Goosse H, Holden PB, Joos F, Kawamiya M, Kicklighter D, Kienert H, Matsumoto K, Mokhov II, Monier E, Olsen SM, Pedersen JOP, Perrette M, Philippon-Berthier G, Ridgwell A, Schlosser A, Schneider von Deimling T, Shaffer G, Smith RS, Spahni R, Sokolov AP, Steinacher M, Tachiiri K, Tokos K, Yoshimori M, Zeng N, Zhao F (2013) Historical and idealized climate model experiments: an EMIC intercomparison. Clim Past 9:1111-1140, doi:10.5194/ сp-9-1111-2013
Ervens B, Turpin B, Weber R (2011) Secondary organic aerosol formation in cloud droplets and aqueous particles (aqSOA): a review of laboratory, field and model studies. Atmos Chem Phys 11(21):11069-11102

Fan SM, Moxim WJ, Levy H (2006) Aeolian input of bioavailable iron to the ocean. Geophys Res Lett 33(7):L07602, doi:10.1029/2005GL024852

Feely RA, Wanninkhof R, Takahashi T, Tans P (1999) Influence of El Niño on the equatorial Pacific contribution to atmospheric $\mathrm{CO}_{2}$ accumulation. Nature 398(6728):597-601

Feely RA, Doney SC, Cooley SR (2009) Ocean acidification: present conditions and future changes in a high- $\mathrm{CO}_{2}$ world. Oceanography 22(4):36-47, doi:10.5670/ Oceanog.2009.95

Feely RA, Sabine CL, Hernandez-Ayon JM, lanson D, Hales B (2008) Evidence for upwelling of corrosive "acidified" water onto the continental shelf. Science 320(5882):1490-1492, doi:10.1126/Science.1155676

Feely RA, Sabine CL, Lee K, Berelson W, Kleypas J, Fabry VJ, Millero FJ (2004) Impact of anthropogenic $\mathrm{CO}_{2}$ on the $\mathrm{CaCO}_{3}$ system in the oceans. Science 305(5682):362-366, doi:10.1126/science. 1097329

Findlay HS, Tyrrell T, Bellerby RGJ, Merico A, Skjelvan I (2008) Carbon and nutrient mixed layer dynamics in the Norwegian Sea. Biogeosciences 5(5):1395-1410, doi:10.5194/Bg-5-1395-2008

Forest CE, Stone PH, Sokolov AP, Allen MR, Webster MD (2002) Quantifying uncertainties in climate system properties with the use of recent climate observations. Science 295(5552):113-117

Friedlingstein P, Cox P, Betts R, Bopp L, Von Bloh W, Brovkin V, Cadule P, Doney S, Eby M, Fung I, Bala G, John J, Jones C, Joos F, Kato T, Kawamiya M, Knorr W, Lindsay K, Matthews H, Raddatz T, Rayner P, Reick C, Roeckner E, Schnitzler K, Schnur R, Strassmann K, Weaver A, Yoshikawa C, Zeng N (2006) Climate-carbon cycle feedback analysis: results from the C(4)MIP model intercomparison. J Climate 19(14):3337-3353, doi:10.1175/jcli3800.1

Friedlingstein P, Meinshausen M, Arora VK, Jones CD, Anav A, Liddicoat SK, Knutti $R$ (2014) Uncertainties in CMIP5 climate projections due to carbon cycle feedbacks. J Climate 27(2):511-526

Friedlingstein P, Dufresne J, Cox P, Rayner P (2003) How positive is the feedback between climate change and the carbon cycle? Tellus B 55(2):692-700, doi:10.1034/j.1600-0889.2003.01461.x

Furukawa T, Takahashi Y (2011) Oxalate metal complexes in aerosol particles: implications for the hygroscopicity of oxalate-containing particles. Atmos Chem Phys 11:4289-4301, doi:10.5194/acp-11-4289-2011

Galloway JN, Dentener FJ, Capone DG, Boyer EW, Howarth RW, Seitzinger SP, Asner GP, Cleveland CC, Green PA, Holland EA, Karl DM, Michaels AF, Porter $J H$, Townsend AR, Vöosmarty CJ (2004) Nitrogen cycles: past, present, and future. Biogeochemistry 70(2):153-226

Goosse H, Brovkin V, Fichefet T, Haarsma R, Huybrechts P, Jongma J, Mouchet A, Selten F, Barriat P-Y, Campin J-M (2010) Description of the Earth system model of intermediate complexity LOVECLIM version 1.2. Geosci Model Dev Discuss 3(1):309-390

Gregory JM, Jones CD, Cadule P, Friedlingstein P (2009) Quantifying carbon cycle feedbacks. J Climate 22(19):5232-5250, doi:10.1175/2009jcli2949.1

Gruber N (1998) Anthropogenic $\mathrm{CO}_{2}$ in the Atlantic Ocean. Global Biogeochem Cy 12(1):165-191, doi:10.1029/97gb03658

Gruber N, Galloway JN (2008) An Earth-system perspective of the global nitrogen cycle. Nature 451(7176):293-296, doi:10.1038/nature06592

Guieu C, Bonnet S, Wagener T, Loÿe-Pilot MD (2005) Biomass burning as a source of dissolved iron to the open ocean? Geophys Res Lett 32(19):L19608, doi:10.1029/2005GL022962

Hajima T, Tachiiri K, Ito A, Kawamiya M (2014) Uncertainty of concentrationterrestrial carbon feedback in Earth System Models. J Climate 27:3425-3445

Han Q, Zender CS, Moore JK, Buck CS, Chen Y, Johansen A, Measures CI (2012) Global estimates of mineral dust aerosol iron and aluminum solubility that account for particle size using diffusion-controlled and surface-areacontrolled approximations. Global Biogeochem Cy 26(2):GB2038, doi:10.1029/ $2011 \mathrm{~GB} 004186$

Hand J, Mahowald N, Chen Y, Siefert R, Luo C, Subramaniam A, Fung I (2004) Estimates of atmospheric-processed soluble iron from observations and a global mineral aerosol model: Biogeochemical implications. J Geophys Res-Atmospheres (1984-2012) 109(D17):D17205, doi:10.1029/2004JD004574

Hargreaves J, Annan J, Edwards N, Marsh R (2004) An efficient climate forecasting method using an intermediate complexity Earth system model and the ensemble Kalman filter. Clim Dynam 23(7-8):745-760

Hargreaves JC, Annan JD, Yoshimori M, Abe-Ouchi A (2012) Can the Last Glacial Maximum constrain climate sensitivity? Geophys Res Lett 39:L24702 
Houghton R, House J, Pongratz J, van der Werf G, DeFries R, Hansen M, Le Quéré C, Ramankutty N (2012) Carbon emissions from land use and land-cover change. Biogeosciences 9(12):5125-5142, doi:10.5194/bg-9-5125-2012

Hurtt G, Chini LP, Frolking S, Betts R, Feddema J, Fischer G, Fisk J, Hibbard K Houghton R, Janetos A (2011) Harmonization of land-use scenarios for the period 1500-2100: 600 years of global gridded annual land-use transitions, wood harvest, and resulting secondary lands. Climatic Change 109(1-2):117-161

IPCC (2007) Climate change 2007: the Physical Science basis. In: Solomon S, Qin D, Manning M, Chen Z, Marquis M, Averyt KB, Tignor M, Miller HL (eds) Contribution of Working Group I to the Fourth Assessment Report of the Intergovernmental Panel on Climate Change. Cambridge University Press, Cambridge/New York, p 996

IPCC (2012) Meeting report of the Intergovernmental Panel on climate change, Expert Meeting on Geoengineering (IPCC Working Group III Technical Support Unit). In: Edenhofer OP-MR, Sokona Y, Field C, Barros V, Stocker TF, Dahe Q, Minx J, Mach K, Plattner G-K, Schlömer S, Hansen G, Mastrandrea M (eds). Potsdam Institute for Climate Impact Research, Potsdam, p 99

IPCC (2013) Climate change 2013: the Physical Science basis (contribution of Working Group I to the Fifth Assessment Report of the Intergovernmental Panel on Climate Change). In: Stocker TF, Qin D, Plattner G-K, Tignor M, Allen SK, Boschung J, Nauels A, Xia Y, Bex V, Midgley PM (eds). Cambridge University Press, Cambridge/New York, p 1535

Ito A, Xu L (2014) Response of acid mobilization of iron-containing mineral dust to improvement of air quality projected in the future. Atmos Chem Phys 14:3441-3459, doi:10.5194/ acp-14-3441-2014

Ito A (2011) Mega fire emissions in Siberia: potential supply of bioavailable iron from forests to the ocean. Biogeosciences 8(6):1679-1697

Ito A (2012) Contrasting the effect of iron mobilization on soluble iron deposition to the ocean in the northern and southern hemispheres. J Meteorol Soc Jpn 90A:167-188, doi:10.2151/Jmsj. 2012-A09

Ito A (2013) Global modeling study of potentially bioavailable iron input from shipboard aerosol sources to the ocean. Global Biogeochem Cy 27(1):1-10

Ito A, Feng Y (2010) Role of dust alkalinity in acid mobilization of iron. Atmos Chem Phys 10(19):9237-9250

Ito A, Kawamiya M (2010) Potential impact of ocean ecosystem changes due to global warming on marine organic carbon aerosols. Global Biogeochem Cy 24(1):GB1012, doi:10.1029/2009GB003559

Ito A, Kok JF, Feng Y, Penner JE (2012) Does a theoretical estimation of the dust size distribution at emission suggest more bioavailable iron deposition? Geophys Res Lett 39:L05807, doi:10.1029/2011 gl050455

Jain AK, Meiyappan P, Song Y, House JI (2013) $\mathrm{CO}_{2}$ emissions from land-use change affected more by nitrogen cycle, than by the choice of land-cover data. Glob Change Biol 19(9):2893-2906

Jain AK, Yang X (2005) Modeling the effects of two different land cover change data sets on the carbon stocks of plants and soils in concert with $\mathrm{CO}_{2}$ and climate change. Global Biogeochem Cy 19(2):GB2015, doi:10.1029/2004GB002349

Jickells T, An Z, Andersen KK, Baker A, Bergametti G, Brooks N, Cao J, Boyd P, Duce R, Hunter K (2005) Global iron connections between desert dust, ocean biogeochemistry, and climate. Science 308(5718):67-71

Johnson M, Meskhidze N (2013) Atmospheric dissolved iron deposition to the global oceans: effects of oxalate-promoted Fe dissolution, photochemical redox cycling, and dust mineralogy. Geosci Model Dev 6:1137-1155

Johnson MS, Meskhidze N, Solmon F, Gassó S, Chuang PY, Gaiero DM, Yantosca RM, Wu S, Wang Y, Carouge C (2010) Modeling dust and soluble iron deposition to the South Atlantic Ocean. J Geophys Res-Atmospheres (1984-2012) 115(D15):D15202, doi:10.1029/2009JD013311

Jones C, Robertson E, Arora V, Friedlingstein P, Shevliakova E, Bopp L, Brovkin V, Hajima T, Kato E, Kawamiya M, Liddicoat S, Lindsay K, Reick CH, Roelandt C, Segschneider J, Tjiputra J (2013) Twenty-first-century compatible $\mathrm{CO}_{2}$ emissions and airborne fraction simulated by CMIP5 Earth system models under four representative concentration pathways. J Climate 26(13):4398-4413, doi:10.1175/jcli-d-12-00554.1

Joos F, Sarmiento JL, Siegenthaler U (1991) Estimates of the effect of Southern Ocean iron fertilization on atmospheric $\mathrm{CO}_{2}$ concentrations. Nature 349:772-775

Journet E, Desboeufs KV, Caquineau S, Colin UL (2008) Mineralogy as a critical factor of dust iron solubility. Geophys Res Lett 35(7):L07805, doi:10.1029/2007GL031589

Kawamura K (2006) Composition and transformation of organic aerosols in the atmosphere. Chikyukagaku (Geochemistry) 40:65-82 (in Japanese)

Keith DW, Parson E, Morgan MG (2010) Research on global sun block needed now. Nature 463(7280):426-427
Kerr RA (2011) Time to adapt to a warming world, but where's the science? Science 334:1052-1053

Kieber R, Hardison DR, Whitehead RF, Willey JD (2003) Photochemical production of Fe(II) in rainwater. Envir Sci Tech 37:4610-4616

Klein Goldewijk K, Beusen A, Janssen P (2010) Long-term dynamic modeling of global population and built-up area in a spatially explicit way: HYDE 3.1 The Holocene 20(4):565-573

Klein Goldewijk K, Beusen A, Van Drecht G, De Vos M (2011) The HYDE 3.1 spatially explicit database of human-induced global land-use change over the past 12,000 years. Global Ecol Biogeogr 20(1):73-86

Klein Goldewijk K, Verburg PH (2013) Uncertainties in global-scale reconstructions of historical land use: an illustration using the HYDE data set. Landscape ecology 28(5):861-877

Knutti R, Stocker TF, Joos F, Plattner G-K (2002) Constraints on radiative forcing and future climate change from observations and climate model ensembles. Nature 416(6882):719-723

Knutti R, Masson D, Masson A (2013) Climate model genealogy: generation CMIP5 and how we got there. Geophys Res Lett 40:1194-1199, doi:10.1002/grl.50256

Kraemer SM (2004) Iron oxide dissolution and solubility in the presence of siderophores. Aquat Sci 66(1):3-18

Kravitz B, Caldeira K, Boucher O, Robock A, Rasch PJ, Alterskjær K, Karam DB, Cole JN, Curry CL, Haywood JM (2013a) Climate model response from the Geoengineering Model Intercomparison Project (GeoMIP). J Geophys Res-Atmospheres 118(15):8320-8332

Kravitz B, Robock A, Forster PM, Haywood JM, Lawrence MG, Schmidt H (2013b) An overview of the Geoengineering Model Intercomparison Project (GeoMIP). J Geophys Res-Atmospheres 118(23):13103-13107

Kravitz B, Robock A, Boucher O, Schmidt H, Taylor KE, Stenchikov G, Schulz M (2011) The geoengineering model intercomparison project (GeoMIP). Atmos Sci Lett 12(2):162-167

Lanzl CA, Baltrusaitis J, Cwiertny DM (2012) Dissolution of hematite nanoparticle aggregates: influence of primary particle size, dissolution mechanism, and solution pH. Langmuir 28(45):15797-15808

Lasaga AC, Soler JM, Ganor J, Burch TE, Nagy KL (1994) Chemical-weathering rate laws and global geochemical cycles. Geochim Cosmochim Acta 58(10):2361-2386

Latham J (1990) Control of Global Warming. Nature 347(6291):339-340, doi:10.1038/347339b0

Le Quéré C, Rödenbeck C, Buitenhuis ET, Conway TJ, Langenfelds R, Gomez A, Labuschagne C, Ramonet M, Nakazawa T, Metzl N (2007) Saturation of the Southern Ocean $\mathrm{CO}_{2}$ sink due to recent climate change. Science 316(5832):1735-1738

Le Quéré C, Andres RJ, Boden T et al (2013) The global carbon budget 1959-2011. Earth Sys Sci Data 5:165-185, doi:10.5194/essd-5-165-2013

Lenton TM, Vaughan NE (2009) The radiative forcing potential of different climate geoengineering options. Atmos Chem Phys 9(15):5539-5561

Lin G, Sillman S, Penner J, Ito A (2014) Global modeling of SOA: the use of different mechanisms for aqueous phase formation. Atmos Chem Phys 14:5451-5475

Liu JF, Horowitz LW, Fan SM, Carlton AG, Levy H (2012) Global in-cloud production of secondary organic aerosols: Implementation of a detailed chemical mechanism in the GFDL atmospheric model AM3. J Geophys Res-Atmospheres 117:D15303, doi:10.1029/2012jd017838

Lobell D, Bala G, Duffy P (2006) Biogeophysical impacts of cropland management changes on climate. Geophys Res Lett 33:L06708, doi:10.1029/2005GL025492

Longhurst AR, Glen Harrison W (1989) The biological pump: profiles of plankton production and consumption in the upper ocean. Prog Oceanogr 22(1):47-123

Luo C, Gao Y (2010) Aeolian iron mobilisation by dust-acid interactions and their implications for soluble iron deposition to the ocean: a test involving potential anthropogenic organic acidic species. Environ Chem 7(2):153-161

Luo C, Mahowald N, Bond T, Chuang PY, Artaxo P, Siefert R, Chen Y, Schauer J (2008) Combustion iron distribution and deposition. Global Biogeochem Cy 22:GB1012, doi:10.1029/2007GB002964

Luo C, Mahowald N, Meskhidze N, Chen Y, Siefert R, Baker A, Johansen A (2005) Estimation of iron solubility from observations and a global aerosol model. J Geophys Res 110:D23307, doi:10.1029/2005JD006059

Mackie DS, Boyd PW, Hunter KA, McTainsh GH (2005) Simulating the cloud processing of iron in Australian dust: $\mathrm{pH}$ and dust concentration. Geophys Res Lett 32:L06809, doi:10.1029/2004GL022122

Mahowald NM, Engelstaedter S, Luo C, Sealy A, Artaxo P, Benitez-Nelson C, Bonnet S, Chen Y, Chuang PY, Cohen DD (2009) Atmospheric iron deposition: global distribution, variability, and human perturbations. Ann Rev Mar Sci 1:245-278 
Martin JH (1990) Glacial-interglacial $\mathrm{CO}_{2}$ change: the iron hypothesis. Paleoceanography 5(1):1-13

Matthews HD, Caldeira K (2008) Stabilizing climate requires near-zero emissions. Geophys Res Lett 35(4):L04705, doi:10.1029/2007GL032388

McGuire AD, Sitch S, Clein JS, Dargaville R, Esser G, Foley J, Heimann M, Joos F, Kaplan J, Kicklighter DW, Meier RA, Melillo JM, Moore B, Prentice IC, Ramankutty N, Reichenau T, Schloss A, Tian H, Williams $\amalg$, Wittenberg U (2001) Carbon balance of the terrestrial biosphere in the twentieth century: analyses of $\mathrm{CO}_{2}$, climate and land use effects with four process-based ecosystem models. Global Biogeochem Cy 15(1):183-206, doi:10.1029/2000gb001298

McNeil Bl, Matear RJ (2008) Southern Ocean acidification: a tipping point at 450-ppm atmospheric $\mathrm{CO}_{2}$. P Natl Acad Sci 105(48):18860-18864

Meiyappan P, Jain AK (2012) Three distinct global estimates of historical land-cover change and land-use conversions for over 200 years. Frontiers of Earth Science 6(2):122-139

Menon S, Denman KL, Brasseur G, Chidthaisong A, Ciais P, Cox PM, Dickinson RE, Hauglustaine D, Heinze C, Holland E (2007) Couplings between changes in the climate system and biogeochemistry. Ernest Orlando Lawrence Berkeley National Laboratory, Berkeley

Merico A, Tyrrell T, Cokacar T (2006) Is there any relationship between phytoplankton seasonal dynamics and the carbonate system? J Marine Syst 59(1-2):120-142

Meskhidze N, Chameides W, Nenes A (2005) Dust and pollution: a recipe for enhanced ocean fertilization? J Geophys Res 110:D03301, doi:10.1029/2004JD005082

Mitchell DL, Finnegan W (2009) Modification of cirrus clouds to reduce global warming. Environ Res Lett 4(4):045102

Montoya M, Griesel A, Levermann A, Mignot J, Hofmann M, Ganopolski A, Rahmstorf S (2005) The earth system model of intermediate complexity CLIMBER-3a. Part I: description and performance for present-day conditions. Clim Dynam 25(2-3):237-263

Myriokefalitakis S, Tsigaridis K, Mihalopoulos N, Sciare J, Nenes A, Kawamura K, Segers A, Kanakidou M (2011) In-cloud oxalate formation in the global troposphere: a 3-D modeling study. Atmos Chem Phys 11(12):5761-5782

NASA Advisory Council (1988) Earth system science: a closer view, Report of the Earth System Sciences Committee. National Aeronautics and Space Administration, Washington, D.C., p 208

Nickovic S, Vukovic A, Vujadinovic M, Djurdjevic V, Pejanovic G (2012) Technical note: high-resolution mineralogical database of dust-productive soils for atmospheric dust modeling. Atmos Chem Phys 12(2):845-855

Oka A, Tajika E, Abe-Ouchi A, Kubota K (2011) Role of the ocean in controlling atmospheric $\mathrm{CO}_{2}$ concentration in the course of global glaciations. Clim Dynam 37(9-10):1755-1770

Orr JC, Fabry VJ, Aumont O, Bopp L, Doney SC, Feely RA, Gnanadesikan A, Gruber N, Ishida A, Joos F, Key RM, Lindsay K, Maier-Reimer E, Matear R, Monfray P, Mouchet A, Najjar RG, Plattner GK, Rodgers KB, Sabine CL, Sarmiento JL, Schlitzer R, Slater RD, Totterdell IJ, Weirig MF, Yamanaka Y, Yool A (2005) Anthropogenic ocean acidification over the twenty-first century and its ximpact on calcifying organisms. Nature 437(7059):681-686, doi:10.1038/nature04095

Paris R, Desboeufs K, Journet E (2011) Variability of dust iron solubility in atmospheric waters: investigation of the role of oxalate organic complexation. Atmos Environ 45(36):6510-6517

Petoukhov V, Claussen M, Berger A, Crucifix M, Eby M, Eliseev A, Fichefet T, Ganopolski A, Goosse H, Kamenkovich I (2005) EMIC Intercomparison Project (EMIP-CO $)_{2}$ : comparative analysis of EMIC simulations of climate, and of equilibrium and transient responses to atmospheric $\mathrm{CO}_{2}$ doubling. Clim Dynam 25(4):363-385

Petoukhov VK (1980) A zonal climate model of heat and moisture exchange in the atmosphere over the underlying layers of ocean and land. In: Golitsyn GS, Yaglom AM (eds) Physics of the atmosphere and the problem of climate. Nauka, Moscow, pp 8-41

Pitman AJ, de Noblet-Ducoudre N, Cruz FT, Davin EL, Bonan GB, Brovkin V, Claussen M, Delire C, Ganzeveld L, Gayler V, van den Hurk BJJM, Lawrence PJ, van der Molen MK, Muller C, Reick CH, Seneviratne SI, Strengers BJ, Voldoire A (2009) Uncertainties in climate responses to past land cover change: first results from the LUCID intercomparison study. Geophys Res Lett 36:L14814, doi:10.1029/ 2009gl039076

Plattner G-K, Knutti R, Joos F, Stocker T, Von Bloh W, Brovkin V, Cameron D, Driesschaert E, Dutkiewicz S, Eby M (2008) Long-term climate commitments projected with climate-carbon cycle models. J Climate 21:2721-2751

Plattner GK, Joos F, Stocker T, Marchal O (2001) Feedback mechanisms and sensitivities of ocean carbon uptake under global warming. Tellus B 53(5):564-592
Pongratz J, Reick CH, Raddatz T, Claussen M (2010) Biogeophysical versus biogeochemical climate response to historical anthropogenic land cover change. Geophys Res Lett 37:L08702, doi:10.1029/2010gl043010

Post WM, Peng T-H, Emanuel WR, King AW, Dale VH, DeAngelis DL (1990) The global carbon cycle. Am Sci 78(4):310-326

Raiswell R, Canfield DE (2012) The iron biogeochemical cycle past and present. Geochem Perspect 1(1):1-220, doi:10.7185/Geochempersp.1.1

Rasch PJ, Tilmes S, Turco RP, Robock A, Oman L, Chen C-CJ, Stenchikov GL, Garcia RR (2008) An overview of geoengineering of climate using stratospheric sulphate aerosols. Philos T R Soc A 366(1882):4007-4037

Reich PB, Hobbie SE (2013) Decade-long soil nitrogen constraint on the $\mathrm{CO}_{2}$ fertilization of plant biomass. Nature Clim Change 3(3):278-282, doi:10.1038/ nclimate 1694

Reich PB, Hobbie SE, Lee T, Ellsworth DS, West JB, Tilman D, Knops JMH, Naeem S, Trost J (2006) Nitrogen limitation constrains sustainability of ecosystem response to $\mathrm{CO}_{2}$. Nature 440(7086):922-925, doi:10.1038/nature04486

Royal Society (2009) Geoengineering the climate: science, governance and uncertainty. Royal Society, London, p 96

Rubasinghege G, Lentz RW, Scherer MM, Grassian VH (2010) Simulated atmospheric processing of iron oxyhydroxide minerals at low pH: roles of particle size and acid anion in iron dissolution. P Natl Acad Sci 107(15):6628-6633

Sabine CL, Feely RA (2007) The oceanic sink for carbon dioxide. In: Reay D, Hewitt N, Grace J, Smith K (eds) Greenhouse gas sinks. CABI Publishing, Oxfordshire, pp 31-49

Sabine CL, Feely RA, Gruber N, Key RM, Lee K, Bullister JL, Wanninkhof R, Wong CS, Wallace DW, Tilbrook B, Millero FJ, Peng TH, Kozyr A, Ono T, Rios AF (2004) The oceanic sink for anthropogenic $\mathrm{CO}_{2}$. Science 305(5682):367-371, doi:10.1126/science.1097403

Saikawa E, Prinn RG, Dlugokencky E, Ishijima K, Dutton GS, Hall BD, Langenfelds R, Tohjima Y, Machida T, Manizza M, Rigby M, O'Doherty S, Patra PK, Harth CM, Weiss RF, Krummel PB, van der Schoot M, Fraser PB, Steele LP, Aoki S, Nakazawa T, Elkins JW (2013) Global and regional emissions estimates for $\mathrm{N}_{2} \mathrm{O}$. Atmos Chem Phys Discuss 13(7):19471-19525, doi:10.5194/acpd-1319471-2013

Sakamoto TT, Komuro Y, Nishimura T, Ishii M, Tatebe H, Shiogama H, Hasegawa A, Toyoda T, Mori M, Suzuki T (2012) MIROC4h—a new high-resolution atmosphere-ocean coupled general circulation model. J Meteorol Soc Jpn 90(3):325-359

Saltzman B (1978) A survey of statistical-dynamical models of the terrestrial climate. Adv Geophys 20:183-304

Santana-Casiano JM, González-Dávila M, Rueda MJ, Llinás O, González-Dávila EF (2007) The interannual variability of oceanic $\mathrm{CO}_{2}$ parameters in the northeast Atlantic subtropical gyre at the ESTOC site. Global Biogeochem Cy 21(1):GB1015, doi:10.1029/2006GB002706

Sarmiento J, Slater R, Dunne J, Gnanadesikan A, Hiscock M (2010) Efficiency of small scale carbon mitigation by patch iron fertilization. Biogeosciences 7(11):3593-3624

Sarmiento JL, Orr JC (1991) Three-dimensional simulations of the impact of Southern Ocean nutrient depletion on atmospheric $\mathrm{CO}_{2}$ and ocean chemistry. Limnol Oceanogr 36(8):1928-1950

Sarmiento JL, Orr JC, Siegenthaler U (1992) A perturbation simulation of $\mathrm{CO}_{2}$ uptake in an ocean general-circulation model. J Geophys Res-Oceans 97(C3):3621-3645, doi:10.1029/91jc02849

Sato $\mathrm{H}$, Ito A, Ito A, Ise T, Kato E (2014) Current status and future of land surface models. Soil Sci Plant Nutri, doi:10.1080/00380768.2014.917593

Sedwick PN, Sholkovitz ER, Church TM (2007) Impact of anthropogenic combustion emissions on the fractional solubility of aerosol iron: Evidence from the Sargasso Sea. Geochem Geophy Geosy 8:Q10Q06, do:10.1029/ 2007gc001586

Sellers WD (1969) A global climatic model based on the energy balance of the earth-atmosphere system. J Appl Meteorol 8(3):392-400

Shevliakova E, Pacala SW, Malyshev S, Hurtt GC, Milly P, Caspersen JP, Sentman LT, Fisk JP, Wirth C, Crevoisier C (2009) Carbon cycling under 300 years of land use change: Importance of the secondary vegetation sink. Global Biogeochem Cy 23:GB2022, doi:10.1029/2007GB003176

Shi Z, Bonneville S, Krom M, Carslaw K, Jickells T, Baker A, Benning LG (2011a) Iron dissolution kinetics of mineral dust at low $\mathrm{pH}$ during simulated atmospheric processing. Atmos Chem Phys 11(3):995-1007

Shi Z, Krom MD, Bonneville S, Baker AR, Bristow C, Drake N, Mann G, Carslaw K, McQuaid JB, Jickells T (2011b) Influence of chemical weathering and aging of iron oxides on the potential iron solubility of Saharan dust during simulated 
atmospheric processing. Global Biogeochem Cy 25:GB2010, doi:10.1029/ 2010GB003837

Shi Z, Krom MD, Jickells TD, Bonneville S, Carslaw KS, Mihalopoulos N, Baker AR, Benning LG (2012) Impacts on iron solubility in the mineral dust by processes in the source region and the atmosphere: a review. Aeolian Res $5: 21-42$

Shindell DT, Schmidt GA (2004) Southern Hemisphere climate response to ozone changes and greenhouse gas increases. Geophys Res Lett 31:L18209, doi:10.1029/2004GL020724

Sholkovitz ER, Sedwick PN, Church TM, Baker AR, Powell CF (2012) Fractional solubility of aerosol iron: synthesis of a global-scale data set. Geochim Cosmochim Ac 89:173-189

Siefert RL, Johansen AM, Hoffmann MR (1999) Chemical characterization of ambient aerosol collected during the southwest monsoon and intermonsoon seasons over the Arabian Sea: labile-Fe (II) and other trace metals. J Geophys Res 104(D):3511-3526

Smith R (2012) The FAMOUS climate model (versions XFXWB and XFHCC): description update to version XDBUA. Geosci Model Dev 5(1):269-276

Sokolov AP, Kicklighter DW, Melillo JM, Felzer BS, Schlosser CA, Cronin TW (2008) Consequences of considering carbon-nitrogen interactions on the feedbacks between climate and the terrestrial carbon cycle. J Climate 21(15):3776-3796

Solmon F, Chuang PY, Meskhidze N, Chen Y (2009) Acidic processing of mineral dust iron by anthropogenic compounds over the north Pacific Ocean. J Geophys Res-Atmospheres 114:D02305, doi:10.1029/2008jd010417

Steinacher M, Joos F, Frolicher TL, Plattner GK, Doney SC (2009) Imminent ocean acidification in the Arctic projected with the NCAR global coupled carbon cycle-climate model. Biogeosciences 6(4):515-533

Stocker BD, Roth R, Joos F, Spahni R, Steinacher M, Zaehle S, Bouwman L, Xu R, Prentice IC (2013) Multiple greenhouse-gas feedbacks from the land biosphere under future climate change scenarios. Nature Clim Change 3(7):666-672, doi:10.1038/nclimate1864

Strong AL, Cullen JJ, Chisholm S (2009) Ocean fertilization: science, policy, and commerce. Oceanography 22:236-261

Tachiiri K, Hargreaves J, Annan J, Oka A, Abe-Ouchi A, Kawamiya M (2010) Development of a system emulating the global carbon cycle in Earth system models. Geosci Model Dev 3(2):365-376

Tachiiri K, Hargreaves JC, Annan JD, Huntingford C, Kawamiya M (2013) Allowable carbon emissions for medium-to-high mitigation scenarios. Tellus B 65:20586, doi:10.3402/tellusb.v65i0.20586

Tachiiri K, Ito A, Hajima T, Hargreaves JC, Annan JD, Kawamiya M (2012) Nonlinearity of land carbon sensitivities in climate change simulations. J Meteorol Soc Jpn 90:259-274

Takahashi T, Sutherland SC, Sweeney C, Poisson A, Metzl N, Tilbrook B, Bates N, Wanninkhof R, Feely RA, Sabine C (2002) Global sea-air $\mathrm{CO}_{2}$ flux based on climatological surface ocean $\mathrm{pCO}_{2}$, and seasonal biological and temperature effects. Deep Sea Res Part II: Top Stud Oceanograph 49(9):1601-1622

Takahashi T, Sutherland SC, Wanninkhof R, Sweeney C, Feely RA, Chipman DW, Hales B, Friederich G, Chavez F, Sabine C (2009) Climatological mean and decadal change in surface ocean $\mathrm{pCO}_{2}$, and net sea-air $\mathrm{CO}_{2}$ flux over the global oceans. Deep Sea Res Part II: Top Stud Oceanograph 56(8):554-577

Taylor KE, Stouffer RJ, Meehl GA (2012) An overview of CMIP5 and the experiment design. B Am Meteorol Soc 93(4):485-498

Thompson DW, Solomon S (2002) Interpretation of recent Southern Hemisphere climate change. Science 296(5569):895-899

Thornton PE, Doney SC, Lindsay K, Moore JK, Mahowald N, Randerson JT, Fung I, Lamarque JF, Feddema JJ, Lee YH (2009) Carbon-nitrogen interactions regulate climate-carbon cycle feedbacks: results from an atmosphere-ocean general circulation model. Biogeosciences 6(10):2099-2120

Timmermann A, Timm O, Stott L, Menviel L (2009) The roles of $\mathrm{CO}_{2}$ and orbital forcing in driving southern hemispheric temperature variations during the last 21000 Yr. J Climate 22:1626-1640, doi:10.1175/2008JCLL2161.1

Tuenter E, Weber S, Hilgen F, Lourens L, Ganopolski A (2005) Simulation of climate phase lags in response to precession and obliquity forcing and the role of vegetation. Clim Dynam 24(2-3):279-295, doi:0.1007/s00382-004-0490-1

Uematsu M (2013) Study on the chemical substance transported to the ocean through the atmosphere. Uminokenkyu (Oceanography in Japan) 22(2):35-45 (in Japanese)

Van Vuuren D, Meinshausen M, Plattner G-K, Joos F, Strassmann KM, Smith SJ, Wigley T, Raper S, Riahi K, De La Chesnaye F (2008) Temperature increase of 21st century mitigation scenarios. P Natl Acad Sci 105(40):15258-15262
Volk T, Hoffert MI (1985) Ocean carbon pumps: analysis of relative strengths and efficiencies in ocean-driven atmospheric $\mathrm{CO}_{2}$ changes. Geoph Monog Series 32:99-110

Watanabe S, Hajima T, Sudo K, Nagashima T, Takemura T, Okajima H, Nozawa T, Kawase H, Abe M, Yokohata T, Ise T, Sato H, Kato E, Takata K, Emori S, Kawamiya M (2011) MIROC-ESM: model description and basic results of CMIP5-20c3m experiments. Geosci Model Dev 4:845-872

Weaver AJ, Eby M, Wiebe EC, Bitz CM, Duffy PB, Ewen TL, Fanning AF, Holland MM, MacFadyen A, Matthews HD (2001) The UVic Earth System Climate Model: model description, climatology, and applications to past, present and future climates. Atmos Ocean 39(4):361-428

Weaver AJ, Sedláček J, Eby M, Alexander K, Crespin E, Fichefet T, PhilipponBerthier G, Joos F, Kawamiya M, Matsumoto K, Steinacher M, Tachiiri K, Tokos K, Yoshimori M, Zickfeld K (2012) Stability of the Atlantic meridional overturning circulation: a model intercomparison. Geophys Res Lett 39:L20709, doi:10.1029/2012GL053763

Weber SL (2010) The utility of Earth system models of intermediate complexity (EMICS). Wiley Interdiscip Rev-Climate Change 1(2):243-252

Webster M, Sokolov AP, Reilly JM, Forest CE, Paltsev S, Schlosser A, Wang C, Kicklighter D, Sarofim M, Melillo J (2012) Analysis of climate policy targets under uncertainty. Climatic Change 112(3-4):569-583

Willey JD, Mullaugh KM, Kieber RJ, Avery GB Jr, Mead RN (2012) Controls on the redox potential of rainwater. Envir Sci Tech 46:13103-13111, doi:10.1021/ es302569j

Yamamoto A, Kawamiya M, Ishida A, Yamanaka Y, Watanabe S (2012) Impact of rapid sea-ice reduction in the Arctic Ocean on the rate of ocean acidification. Biogeosciences 9(6):2365-2375, doi:10.5194/Bg-9-2365-2012

Yao X, Fang M, Chan CK (2002) Size distributions and formation of dicarboxylic acids in atmospheric particles. Atmos Environ 36(13):2099-2107

Yoshikawa C, Kawamiya M, Kato T, Yamanaka Y, Matsuno T (2008) Geographical distribution of the feedback between future climate change and the carbon cycle. J Geophys Res 113(G3):G03002, doi:10.1029/2007jg000570

Yu JZ, Huang X-F, Xu J, Hu M (2005) When aerosol sulfate goes up, so does oxalate: implication for the formation mechanisms of oxalate. Envir Sci Tech 39(1):128-133

Zaehle S, Ciais P, Friend AD, Prieur V (2011) Carbon benefits of anthropogenic reactive nitrogen offset by nitrous oxide emissions. Nat Geosci 4(9):601-605, doi:10.1038/ngeo 1207

Zaehle S, Friedlingstein P, Friend AD (2010) Terrestrial nitrogen feedbacks may accelerate future climate change. Geophys Res Lett 37:L01401, doi:10.1029/ 2009gl041345

Zhuang G, Yi Z, Duce RA, Brown PR (1992) Link between iron and sulphur cycles suggested by detection of $\mathrm{Fe}(\mathrm{n})$ in remote marine aerosols. Nature 355:537-539

Zickfeld K, Eby M, Matthews HD, Schmittner A, Weaver AJ (2011) Nonlinearity of carbon cycle feedbacks. J Climate 24(16):4255-4275

Zickfeld K, Eby M, Weaver AJ, Alexander K, Crespin E, Edwards NR, Eliseev AV, Feulner G, Fichefet T, Forest CE, Friedlingstein P, Goosse H, Holden PB, Joos F, Kawamiya M, Kicklighter D, Kienert H, Matsumoto K, Mokhov II, Mokhov E, Olsen SM, Pedersen JOP, Perrette M, Philippon-Berthier G, Ridgwell A, Schlosser A, Schneider Von Deimling T, Shaffer G, Sokolov A, Spahni R et al (2013) Long-term climate change commitment and reversibility: an EMIC intercomparison. J Climate 26(16):5782-5809

\section{doi:10.1186/s40645-014-0029-y}

Cite this article as: Hajima et al:: Modeling in Earth system science up to and beyond IPCC AR5. Progress in Earth and Planetary Science 2014 1:29. 